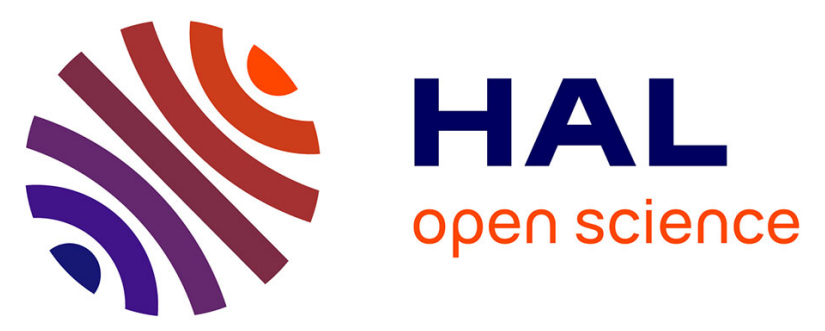

\title{
Last Glacial palaeoenvironments at Lascaux, southwest France, with special emphasis on MIS 4 (Ognon II interstadial)
}

Pascal Bertran, Gisèle Allenet, Michel Brenet, Jean-Pierre Chadelle, Marie-France Dietsch-Sellami, Jean-Pierre Hebrard, Georges Madelaine, Norbert Mercier, Vincent Pasquet, Philippe Ponel, et al.

\section{To cite this version:}

Pascal Bertran, Gisèle Allenet, Michel Brenet, Jean-Pierre Chadelle, Marie-France Dietsch-Sellami, et al.. Last Glacial palaeoenvironments at Lascaux, southwest France, with special emphasis on MIS 4 (Ognon II interstadial). Palaeogeography, Palaeoclimatology, Palaeoecology, 2016, 449, pp.149-165. 10.1016/j.palaeo.2016.02.008 . hal-01444675

\section{HAL Id: hal-01444675 \\ https://hal.science/hal-01444675}

Submitted on 15 Jul 2020

HAL is a multi-disciplinary open access archive for the deposit and dissemination of scientific research documents, whether they are published or not. The documents may come from teaching and research institutions in France or abroad, or from public or private research centers.
L'archive ouverte pluridisciplinaire $\mathbf{H A L}$, est destinée au dépôt et à la diffusion de documents scientifiques de niveau recherche, publiés ou non, émanant des établissements d'enseignement et de recherche français ou étrangers, des laboratoires publics ou privés. 


\section{Last Glacial palaeoenvironments at Lascaux, southwest France, with special emphasis on MIS 4 (Ognon II interstadial)}

Pascal Bertran ${ }^{\mathrm{a}, \mathrm{b}}{ }_{*}$, Gisèle Allenet ${ }^{\mathrm{c}}$, Michel Brenet ${ }^{\mathrm{d}, \mathrm{b}}$, Jean-Pierre Chadelle ${ }^{\mathrm{e}}$, Marie-France Dietsch-Sellami d,f ,Jean-Pierre Hébrard ${ }^{g}$, Georges Madelaine ${ }^{\mathrm{h}}$, Norbert Mercier ${ }^{\mathrm{i}}$, Vincent Pasquet ${ }^{\mathrm{a}}$, Philippe Ponel ${ }^{\mathrm{j}}$, Alain Queffelec $^{\mathrm{b}}$, Colette Sirieix ${ }^{\mathrm{k}}$

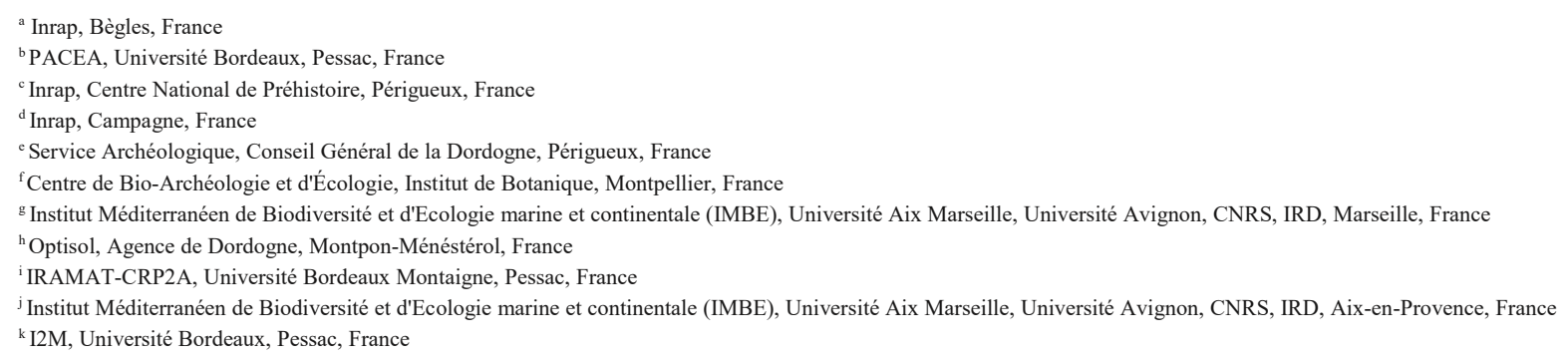

\section{Abstract}

A deep sequence of Last Glacial peats and slope deposits at the foot of the Lascaux hill was investigated using a large array of methods (geology, geophysics, ${ }^{14} \mathrm{C}$ and OSL dating, palynology, macro-remain analysis, entomology). The peaty levels, OSL dated to between $\sim 73$ and $60 \mathrm{ka}$, are found within a doline developed in a fluvial terrace of the Vézère River. These gyttja and chalky gyttja deposits covered by fen peat yielded abundant beetle and plant (seeds, pollen) remains. Palaeoecological reconstructions suggest a cool steppe with willow stands compatible with an interstadial of marine isotopic stage (MIS) 4, probably Ognon II (GI-19.2). Aquatic and hygrophilous plants (sedges), which reflect local vegetation, and their dependent insects are equally well represented in the record. The peats are covered by a sequence of slope deposits: a coarse-grained lower unit deposited during late MIS 4, overlain by a heavily decalcified sandy unit with a boreal soil complex correlated with early MIS 3, and finally, a coarsegrained, calcareous unit formed during late MIS 3 and MIS 2 in connection with slope dynamics typical of periglacial environments. The palaeosols yielded a small Middle Palaeolithic lithic assemblage.

Keywords: MIS 4 peat ; Ognon II interstadial ; Weichselian slope deposits ; Southwest France ; Palaeoecology ; Palaeotemperatures

\section{Introduction}

Detailed palaeoecological studies of Pleistocene continental zones are largely dependent on the discovery of lake and peat deposits containing remains of plants and small animals. These types of data are, however, still rare for glacial periods in France due to that fact that not only did low plant biomass during these phases not favor the accumulation of large quantities of organic materials but the likelihood of these types of accumulations being preserved is fairly low. This is particularly the case for southwest France where the still limited data available for reconstructing palaeovegetation derives from either peripheral mountain ranges (Pyrenees: Jalut et al., 1988; Andrieu et al., 1993; Massif Central: de Beaulieu and Reille, 1984; de Beaulieu et al., 2001) or marine cores from the Bay of Biscay 
(MD04-2845 core, Sánchez-Goñi et al., 2008, 2012). Additionally, reconstructing precise ecological conditions of continental milieus is complicated by the fact that these marine cores incorporate inputs from large areas drained by rivers.

Archaeological surveys at the future site of the International Centre of Parietal Art (Lascaux 4) near the village of Montignac uncovered peat deposits about $6 \mathrm{~m}$ below the current level of the Vézère Valley. Here we present results of a comprehensive, multidisciplinary study of these deposits and their context, evaluating their potential for reconstructing detailed pre-Holocene palaeoenvironmental conditions potentially contemporaneous with the prehistoric occupation of Lascaux. The geometry of the different sedimentary formations was determined from observations of profiles, geotechnical boreholes and electrical tomography profiles. Additional analyses (grain size, thin sections, geochemistry) were carried out in order to further characterize the depositional environment of each lithostratigraphic unit, and peats were sampled for pollen, plant and beetle remains for palaeoenvironmental reconstruction. Finally, a series of radiometric dates (radiocarbon and optically stimulated luminescence) was obtained in order to build a secure chronological framework for the deposition of the peat deposits.

\section{Geological and environmental context}

The site (WGS84 coordinates: $45.0576^{\circ} \mathrm{N}, 1.1691^{\circ} \mathrm{E}$, altitude $90 \mathrm{~m}$ a.s.1.) lies on a low, potentially post-glacial alluvial terrace referred to as "Fxa" (infoterre.brgm.fr, sheet of Terrasson, Guillot et al., undated) on the right bank of the Vézère River, near the village of Montignac (Fig. 1). Survey work comprising test trenches and boreholes at the foot of a long Cretaceous formation of Middle Coniacian (c4b) to Lower Santonian (c5a) yellowish bioclastic, chalky or sandy limestones uncovered alluvial deposits at an elevation of ca. $80 \mathrm{~m}$ a.s.l. or 5 to $7 \mathrm{~m}$ above the current river bed. The entrance to Lascaux Cave, which is developed in the $\mathrm{c} 4 \mathrm{~b}$ limestone, is located about $450 \mathrm{~m}$ from the site on the overlying plateau. This is covered by a clayey sand formation (Rc-e) interpreted as weathering products of the c5a limestone. 


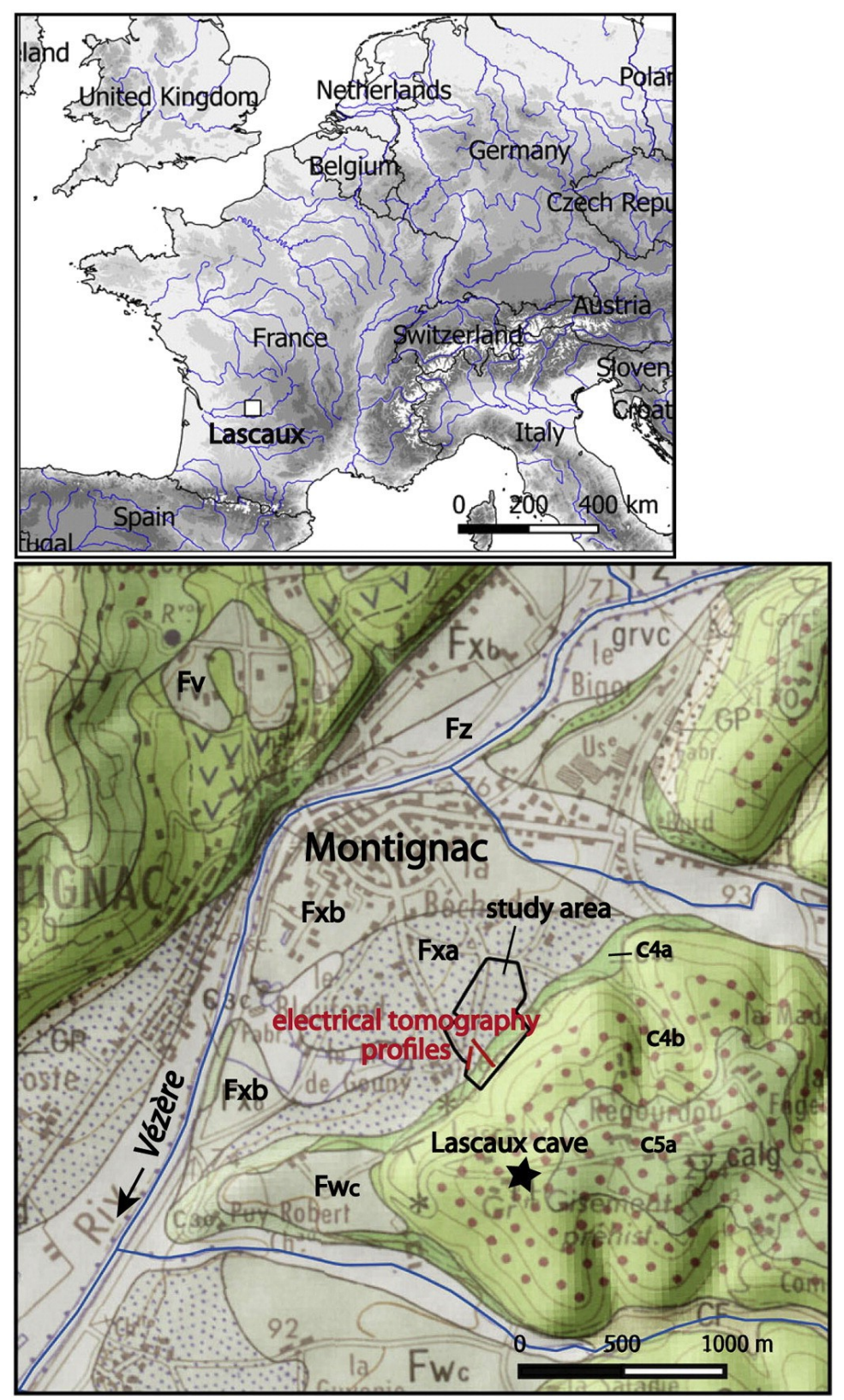

Fig. 1. Extract of the 1:50,000 geological map, sheet of Terrasson (infoterrre.brgm.fr, Guillot et al., undated), draped on the $25 \mathrm{~m}$ MNT of the Institut Géographique National (IGN), and site location.

At the foot of the slope, outcrops of white micritic limestones (c4b) and marl beds (c4a) are covered by slope deposits. The cores show the lithofacies underlying the Fxa alluvium to consist primarily of yellowish sandy limestone (c3c, Upper Turonian) made up of alternating hard limestone units, yellowish loose sand, sandy clay, several red clay levels, and fine gravel levels up to several meters thick. All these loose levels are of karstic origin.

Current weather data from the town of Bergerac (http://climatedata. e-monsite.com) located 60 kilometers southwest of Lascaux for the period between 1981 and 2010 reveal a MAAT of $13^{\circ}$ and a MAP of $801 \mathrm{~mm}$. TMax, or the average temperature of the warmest month (July), and TMin, that of the coldest month (January), are $21^{\circ} \mathrm{C}$ and $5.5^{\circ} \mathrm{C}$ respectively. According to the French Map of Potential Vegetation (Leguédois et al., 2015), Lascaux is situated within the calcicole pedonculate oak forest with patches of holm oaks on the plateaus. 


\section{Methods}

A trench was dug parallel to the slope in order to expose the area that produced the peat levels. Four cores (SS1, SS2, SS5 and SS2bis) were recovered using a Shelby sampler to sound the deepest levels, including the peats, after preliminary surveys with a penetrometer (Optisol). Data from nearby geotechnical boreholes were integrated into a GIS (Quantum GIS software), with the limits of the lithostratigraphic units interpolated to reconstruct their geometry.

Additional information was also obtained from two electrical tomography profiles, one at the foot of the slope and the other approximately parallel to the trench. The I2M laboratory (Université Bordeaux) uses a SYSCAL Pro switch 72 (IRIS Instruments) resistivity meter with a pole-dipole array (Loke, 2014). To eliminate the effects of asymmetry due to the remote electrode, we combined the measurements with the forward and reverse pole-dipole. The array was based on 72 electrodes with two different electrode spacings $(1.5 \mathrm{~m}$ and $1 \mathrm{~m})$ resulting in a total array length of $106.5 \mathrm{~m}$ and $71 \mathrm{~m}$, respectively. Resistivity models were obtained by inverting the apparent electrical resistivity with the Res2DInv@ software using a L1 norm inversion (Loke et al., 2003; Loke, 2014).

Three cores (SS1, SS2 and SS5) were analyzed at the EPOC laboratory (Université Bordeaux). After splitting, cores were photographed and X-rayed with a SCOPIX image system (Cegelec/Alliance Vision, RX tube $160 \mathrm{KV}, 100 \mathrm{~W}$ X Neptune - Oxford). ED-XRF analysis was carried out using an XRF Core Scanner AVAATECH, with chemical composition expressed as a ratio of silicium $(\mathrm{Si})$.

Thirty samples were also collected from the site or potential sedimentary sources in the area for chemical analysis at the PACEA laboratory (Université Bordeaux). Samples were separated by water sieving using a $63 \mu \mathrm{m}$ mesh, with the sand fraction ground and transformed into pellets for X-ray fluorescence (ED-XRF) using a portable SPECTRO X-SORT $(40 \mathrm{kV}, 50 \mu \mathrm{A})$. Measurements were recorded in an air path with an acquisition time of $300 \mathrm{~s}$. The device was calibrated beforehand using a method comparable to that described by Lucas-Tooth and Price (1961) using ICP-AES/ICP-MS compositions from 16 samples of regional Neogene and Quaternary sediments obtained by the SARM-CRPG laboratory in Nancy. Only elements for which a correlation coefficient (R2) greater than 0.9 between ED-XRF and ICP-AES/ICP-MS values were taken into account (Fig. SI_1). Elements lighter than Si are not detected with this device. Multivariate analysis was carried out using the biplot for compositional data methodology described by Aitchison and Greenacre (2002). Before analysis, values below the detection limit were treated according to the method proposed by MartinFernandez et al. (2003). Only those elements for which more than $80 \%$ of the values were above the detection limit were retained for statistical analysis using the CoDaPack software (Thio-Henestrosa and Comas, 2011).

Thin sections from ten undisturbed sediment blocks were vacuum impregnated with polyester resin following the method described by Guillore (1980) and prepared at the PACEA laboratory (Université Bordeaux). The terminology used to describe the thin sections is adapted from Bullock et al. (1985).

Charcoals fragments were collected for radiocarbon (Poznan Radiocarbon Laboratory) from cross-sections in the upper part of the sequence and OSL samples (IRAMAT-CRP2A, Université Bordeaux-Montaigne) were collected either using metal tubes driven into a wall of the trench or directly from the SS2bis core. SS2bis was drilled $0.8 \mathrm{~m}$ west of SS2 in order to recover an almost identical stratigraphic sequence. The final section of the core (depths between 6.0 and $6.8 \mathrm{~m}$ ) was protected from light by an opaque PVC jacket prior to analysis. Samples for OSL dating were chemically treated to extract and purify the quartz fraction. Uranium (U), thorium (Th) and potassium $(\mathrm{K})$ content was measured in the laboratory on a fraction of retained sediment. The $\gamma$ dose 
for the sample taken in the trench was measured on-site using a portable spectrometer and calculated from the U, Th and $\mathrm{K}$ contents for the core samples. The dose accumulated by the analyzed quartz grains was determined for each sample using the SAR protocol (single aliquot regenerative) (Murray and Wintle, 2000) applied to aliquots consisting of approximately a thousand grains. The accumulated dose (De) for each sample corresponds to an averaged value from the measured aliquots.

The extraction protocol for pollen grains is adapted from that recommended by Girard and Renault-Miskovsky (1969) and was carried out at the Centre National de Préhistoire (CNP, Périgueux). The analysis is based on the reliability criteria proposed by Reille (1990) with a minimum of 300 grains counted and 21 taxa identified. Data was processed with the Gpalwin software (Goeury, 1988). The weight of the 27 sediment samples is tied to organic content, ranging between 1 and $10 \mathrm{~g}$ for wet sediment and $0.4 \mathrm{~g}$ to $8.5 \mathrm{~g}$ for dry sediment. Macro-remains from the $300 \mu \mathrm{m}$ sieve residue of 63 samples from core SS2 were sorted at the Inrap (Campagne) under a stereo-microscope, producing a total of 267 vegetal remains.

After disintegration of the sediment under water and sieving using a $300 \mu \mathrm{m}$ mesh, the beetle remains from 111 samples of peat were separated and concentrated by flotation in oil (Coope, 1986). The remains were then hand-sorted under a stereo-microscope. In the end, 67 samples from core SS2 and 43 samples from core SS5 were treated at the Centre Archéologique de la Vallée de l'Oise (CRAVO). An additional sample corresponding to a larger volume of sediment collected during the archaeological survey and identified as "Montignac Trench 56/81.57" was also treated at the Institut Méditerranéen de Biodiversité et d'Ecologie (IMBE). The extracted material was studied at the IMBE using a reference collection of one of the present authors (Ph. P). The adopted nomenclature follows that of Fauna Europaea (2011), with palaeoecological interpretations based essentially on the works of Koch (1989-1992) and Lindroth (1985-1986).

\section{Results}

\subsection{Stratigraphy}

\subsubsection{Main sedimentary units and geometry of the deposits}

Overall, the stratigraphy (Fig. 2) observed at the foot of the slope comprises three main sedimentary units overlying the limestone (from top to bottom, Fig. 2):

(1) Sandy to gravelly, more or less calcareous slope deposits measuring up to $7 \mathrm{~m}$ in thickness;

(2) Thin, locally preserved peat levels that do not exceed $0.7 \mathrm{~m}$ in thickness;

(3) Siliciclastic alluvial gravel up to $3 \mathrm{~m}$ thick. 


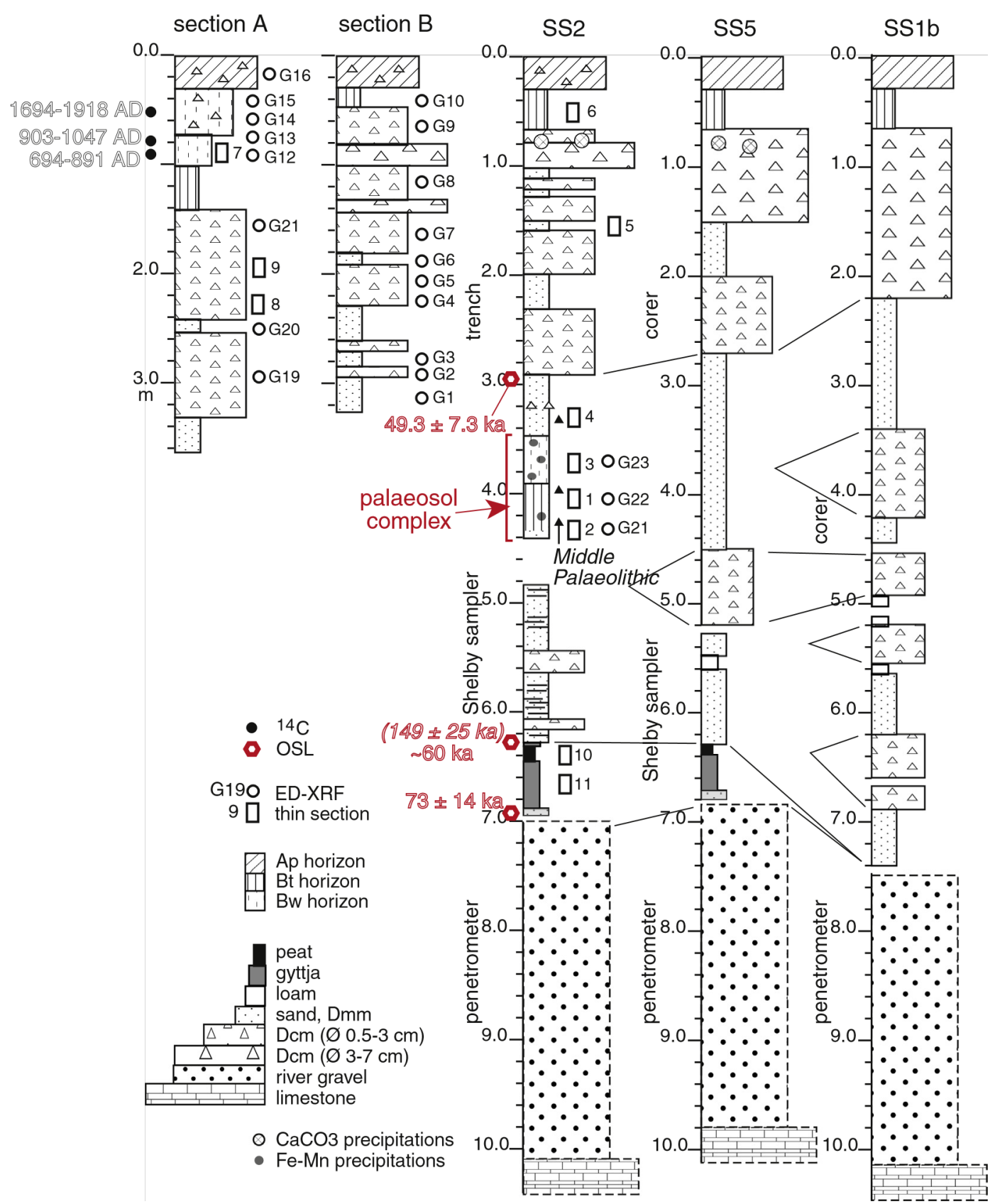

Fig. 2. Schematic stratigraphy of the Pleistocene formations at the slope foot, from a combination of observations made on trenches, cores and penetrometric data (the latter indicated by dotted lines), and location of the samples. Dmm: matrix-supported layer, Dcm: clast-supported layer.

A relatively precise geometry of the main units was determined based on data from the borehole survey and electrical tomography profiles. Extrapolations from the borehole data reveal the top of the limestone bedrock to be an elongated depression subparallel to the slope (Fig. 3A). The tomographic profile perpendicular to the slope further supports the presence of a depression (Fig. 4A) that probably corresponds to a palaeochannel of the Vézère. A second profile parallel to the axis of this structure produced evidence for a very irregular substrate (Fig. 4B). Ten meter-wide karstic depressions cut into the limestone and filled by a material with a lower resistivity likely represent the gravel and sand units detected during the borehole survey. 

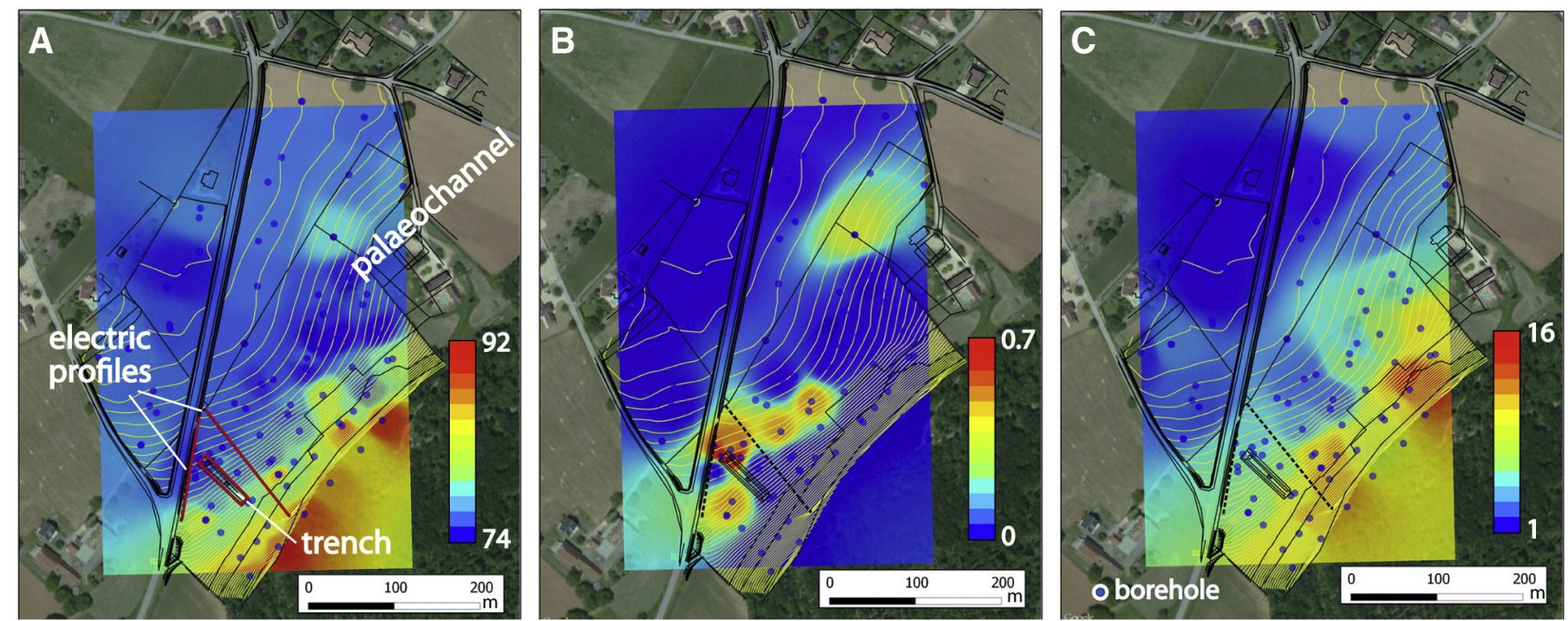

Fig. 3. A - altitude of the limestone substrate from the geotechnical data and location of the trench and the electrical tomography profiles; $\mathrm{B}-$ thickness of the peats, $\mathrm{C}-$ thickness of the slope deposits. The data were treated with the software Quantum GIS.

The peat deposits overlying the gravel are found in the form of highly localized lenses in small depressions running alongside the palaeochannel (Fig. 3B). The location of the identified karst features (dolines) at both ends of the second electrical tomography profile (Fig. 4B) is in good agreement with the two peaty depressions visible on the interpolation maps.

Overall, survey work reveals a sedimentary sequence developed in a palaeochannel of the Vézère that was altered by dolines, and subsequently covered by slope apron deposits with a maximum thickness of close to $7 \mathrm{~m}$ at the foot of the slope in the surveyed area. These deposits are almost 15 $\mathrm{m}$ thick approximately $150 \mathrm{~m}$ to the northeast and decreases rapidly towards the river (Fig. 3C). The apron is cut by an alluvial fan that developed at the mouth of a gully immediately to the southwest of the study area. 


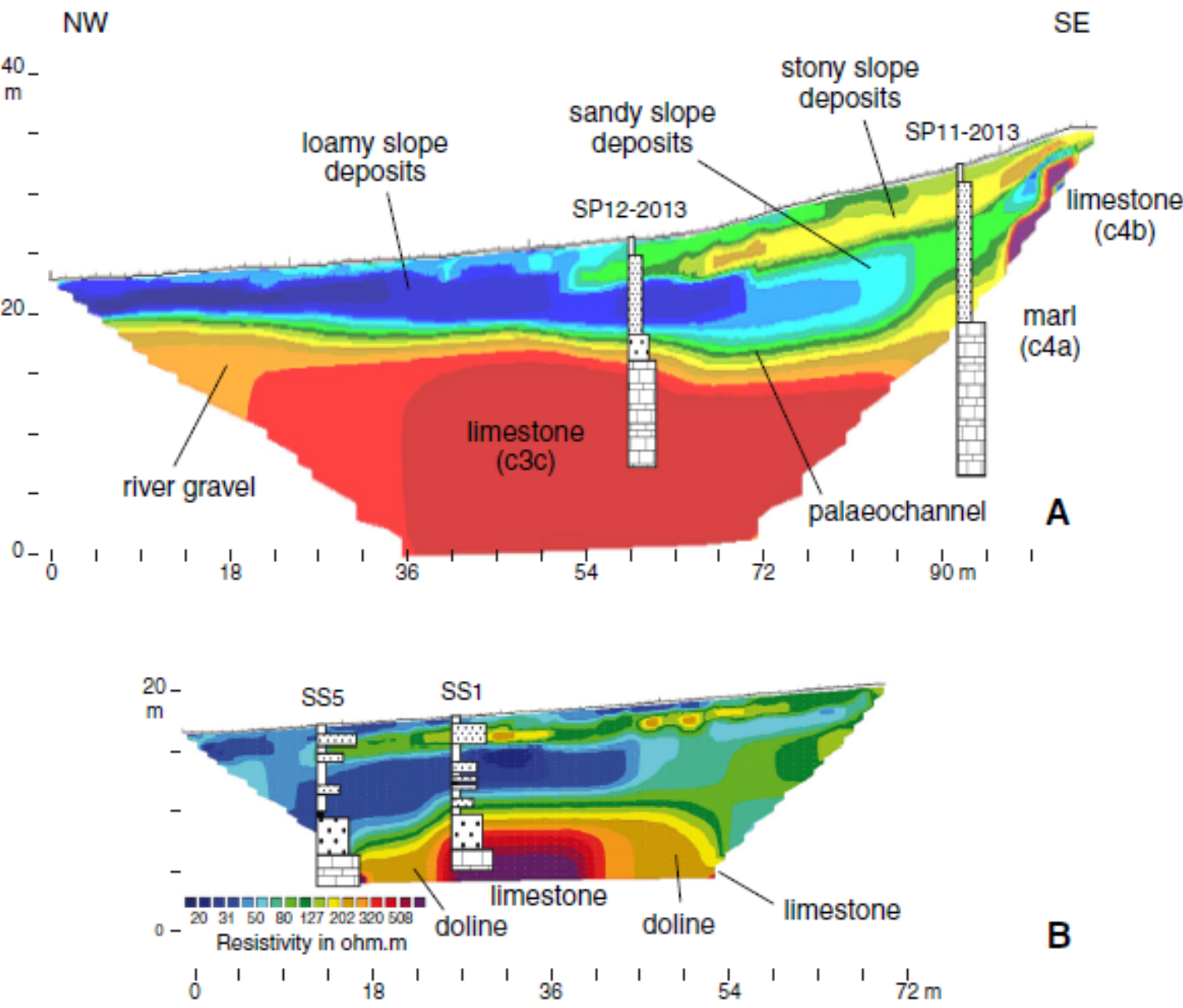

Fig. 4. A - electrical tomography profile perpendicular to the slope (Profile 1); B - profile parallel to the slope (Profile 2)

\subsubsection{Slope deposit stratigraphy}

Detailed observations of the slope deposits visible in the trench sections reveal significant lateral upslope to downslope facies changes (facies codes are adapted from Miall, 1996):

(1) Loosely stratified, light yellow-brown clast-supported calcareous deposits (Dcm) (Fig. 5A). The small angular clasts ( 0.5 to $3 \mathrm{~cm}$ on average) are preferentially oriented parallel to the slope (Fig. 6). This lithofacies forms the major portion of the upslope section and the upper $2 \mathrm{~m}$ of the downslope section. Localized downslope overturning of strata (Fig. 5B) and lenses of sorted coarse sand (Sh, Fig. 5A) are also visible. The low gradient (maximum $15^{\circ}$ upslope to $5^{\circ}$ downslope) suggests the clastic material to be connected to debris flow or solifluction rather than simple rockfall scree. The preferential orientation of the clasts equally points to periglacial solifluction, which may have occurred at least during the final phase of deposition (Bertran et al., 1997). Strata overturning is also typical of ground deformation in periglacial contexts (Ballantyne and Harris, 1994). Thin sections reveal a washed sandy matrix and silt cappings on the gravel (Fig. 7C) connected to heavy leaching associated with the formation of segregation ice. This type of microfacies has been mainly described in soliflucted deposits (Harris and Ellis, 1980; Van Vliet-Lanoë, 1985). An additional sample consists of gravel scattered in an abundant silty sand matrix with a vesicular porosity (Fig. 7D) triggered by liquefaction. Similar 
microfacies are known from periglacial deposits associated with liquefaction following thawing (Van Vliet-Lanoë, 2010) or debris flows (Bertran and Texier, 1999).

(2) Isolated lenses of coarse limestone clasts ( Go). Lenses occur primarily in the downslope part and in the upper $2 \mathrm{~m}$ of the sequence

(Fig. 5C). Planar or slightly linear fabrics (Fig. 6) indicate these levels to represent debris deposited by wet snow avalanches (Blikra and Nemec, 1998; Jomelli and Bertran, 2001). This is supported by an accumulation on gentle slopes $\left(5-7^{\circ}\right)$, the coarse size of the clasts, the almost total lackof fine matrixdue toscraping of the superficial coarse-grained veneer of the talus by avalanches, and the absence of a preferential clast orientation.

Lenses of yellowish-brown sandy-silt matrix-supported deposits (Dmm) interbedded in the Dcm facies, especially in the downslope area (Fig. 5D). These beds are at times deformed into stretched folds. This facies represents mudflow deposits triggered by heavy rainfall (Van Steijn, 1996; Blair and McPherson, 1998) and subsequently deformed by periglacial processes. In thin section, the samples are characterized by clasts scattered in a dense and homogeneous finegrained matrix.

(3) Massive, yellow-brown decalcified silty sand deposits $(\mathrm{Sm})$ found primarily in the lower part of the sequence. Interpretable as overland flow deposits and/or mudflows, the lack of bedding is probably due to secondary bioturbation.

(4) Massive, brown (slightly humic) matrix-supported deposits with 10-20\% subangular (weathered) clasts scattered in a silt-sand matrix. These levels form the upper part of the sequence and correspond to agricultural colluvium that covers two successive generations of anthropogenic terraces. Local lenses of large blocks likely derive from the collapse of ancient walls (Fig. 5E). In thinsection (Fig. 7A), the samples are characterized by a decalcified organicstained matrix, fissure porosity and secondary accumulations of root carbonates (Durand et al., 2010). 


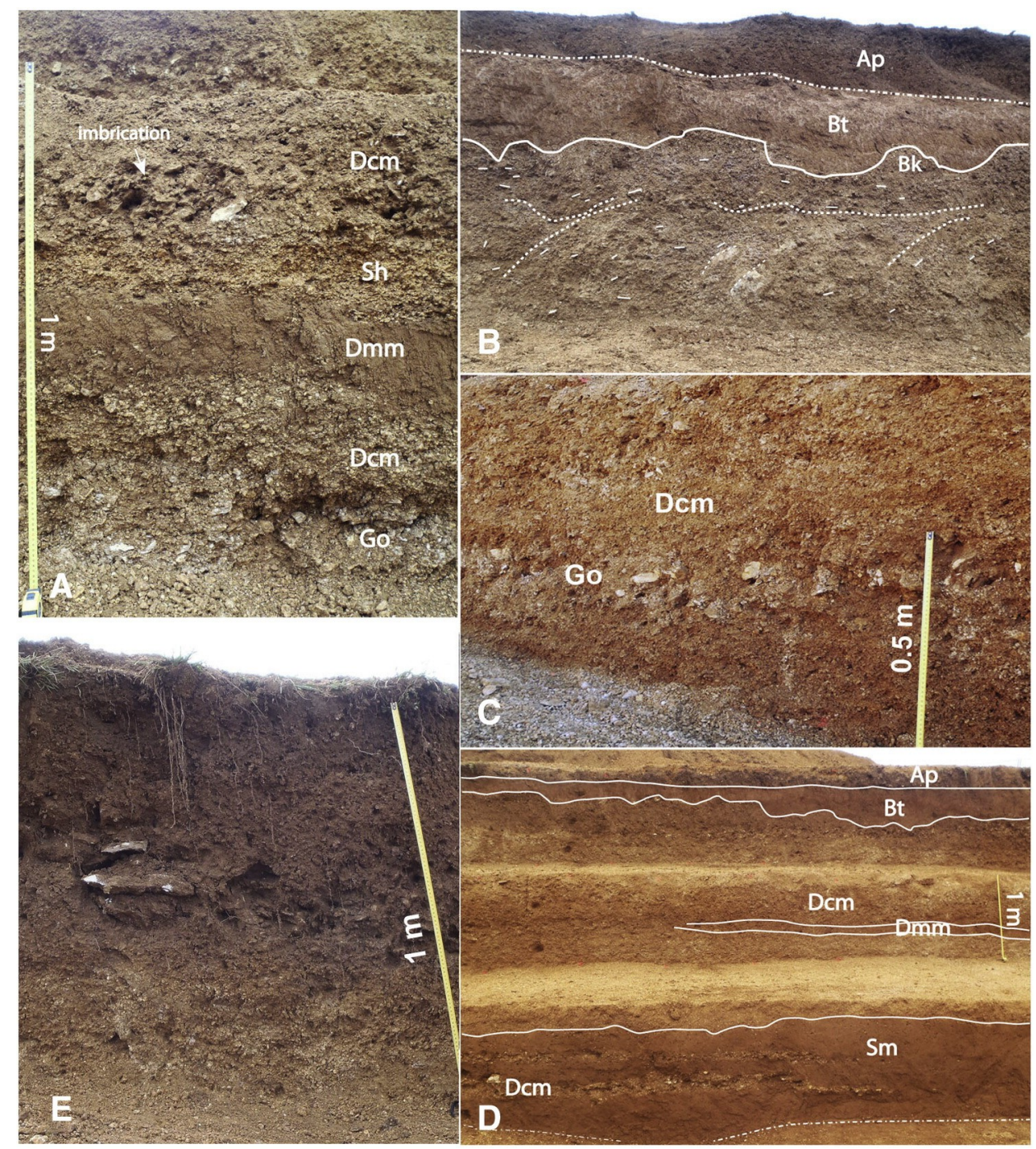

Fig. 5. Main lithofacies. A - median part of the trench (Dcm: clast-supported gravel, Sh: bedded sand, Dmm: matrixsupported bed, Go: coarse gravel without interstitial matrix); B - downslope overturning of the strata in the upslope part of the trench (Bt: argic horizon); C - coarse bed (facies Go) intercalated in clast-supported slope deposits (Dcm); D matrixrich beds (Dmm) in the downslope part of the trench; E - slightly humic colluvium overlying a cultivation terrace. The coarse bed in the middle corresponds to a collapsed stone wall. 


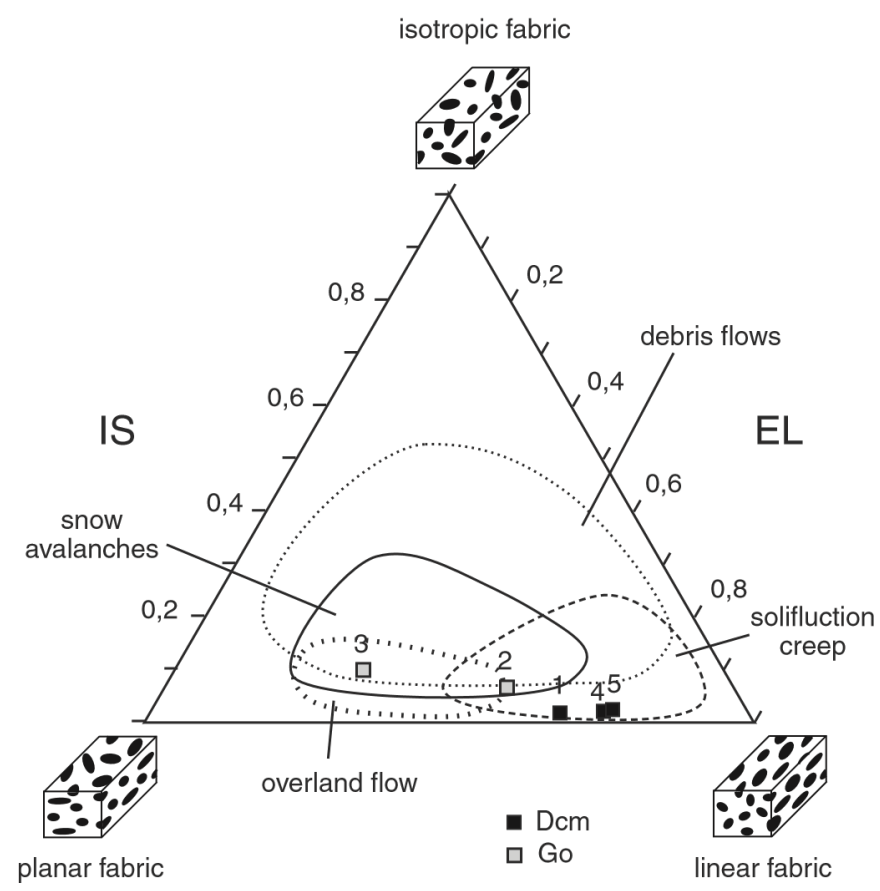

Fig. 6. Fabric of coarse-grained levels (Benn's (1994) diagram) and areas of some sedimentary processes, from Bertran et al. (1997). The samples 1, 4 and 5 correspond to lithofacies Go, and the numbers 2 and 3 to lithofacies Dcm.

Overall, the trench sequence (from bottom to top) can be divided into three main units:

- Two predominantly fine-grained decalcified layers ( $\mathrm{Sm}, \mathrm{Dmm}$ ) measuring up to $2 \mathrm{~m}$ in thickness. These layers correspond to bioturbated colluvium in the distal portion of the slope. - Two, approximately $4 \mathrm{~m}$ thick upslope and $2 \mathrm{~m}$ thick downslope, calcareous coarse-grained layers (Dcm, Go) deposited in a periglacial environment, as demonstrated by avalanche deposits, overturning of strata, linear fabrics and microfacies. While these proximal talus deposits prograde over finer-grained distal colluvium, electrical tomography data indicate this unit to spread considerably downslope, forming a distinct sedimentary unit overlying the finegrained material (Fig. 4). This difference clearly reflects a change in sedimentation probably related to the influence of periglacial conditions.

- Holocene agricultural terraces at the top of the sequence covered by slightly humic colluvium.

\subsubsection{Soils and palaosols}

The complex superficial soil profile is composed of four horizons (nomenclature is taken from the World Reference Base for Soil Resources, FAO-WRB, 2006): (1) a dark brown, stony plough layer (Ap horizon), (2) a brown (10YR 4/4) stony cambic horizon with a polyedric structure (Bw) developed on agricultural colluvium, (3) a light brown (7.5YR 5/6) decalcified horizon with a polyedric structure (Fig. 5B) and (4) a Bk horizon with secondary carbonate precipitations. Horizon 3 is discontinuous and locally eroded by agricultural terraces. The lower boundary is irregular and corresponds to a decalcification front. It appears in thin section as a fine-grained material with a fissure and biogallery porosity and with hyaline, reddish-brown illuvial clay accumulations (Fig. 7B) coating the cavities or partially integrated into the matrix. These characteristics indicate an argic (Bt) horizon representing a Holocene luvisol preceding the deposition of the agricultural colluvium. 
A second argic horizon (IIIBth) was identified downslope of the trench between a depth of 3.9 and $4.5 \mathrm{~m}$. This light brown decalcified horizon (7.5YR 5/6) with lighter brown (10YR 6/6) and black (FeMn precipitations) mottling has a predominantly biological porosity and brown illuvial clay coatings (Fig. 7F). The brown colour is likely due to organic matter adsorbed on clay particles. Micritic carbonate precipitation forming diffuse nodules around biogalleries are present in the lower part of the horizon. Bth horizons are typical of current humic luvisols in boreal contexts under forest or foreststeppe ("grey forest soils"/greyzems: Bronger, 1978; Miedema et al., 1999).

The level overlying the IIIBth horizon (depth of 3.5 to $3.9 \mathrm{~m}$ ) is composed of decalcified sand with a well-developed biological porosity and black Fe-Mn spots. In thin section, brown silty-clay intercalations are common (Fig. 7E). This level is interpreted as a slightly hydromorphic cambic horizon (IIBg) that may reflect weaker soil formation compared to the underlying argic horizon.

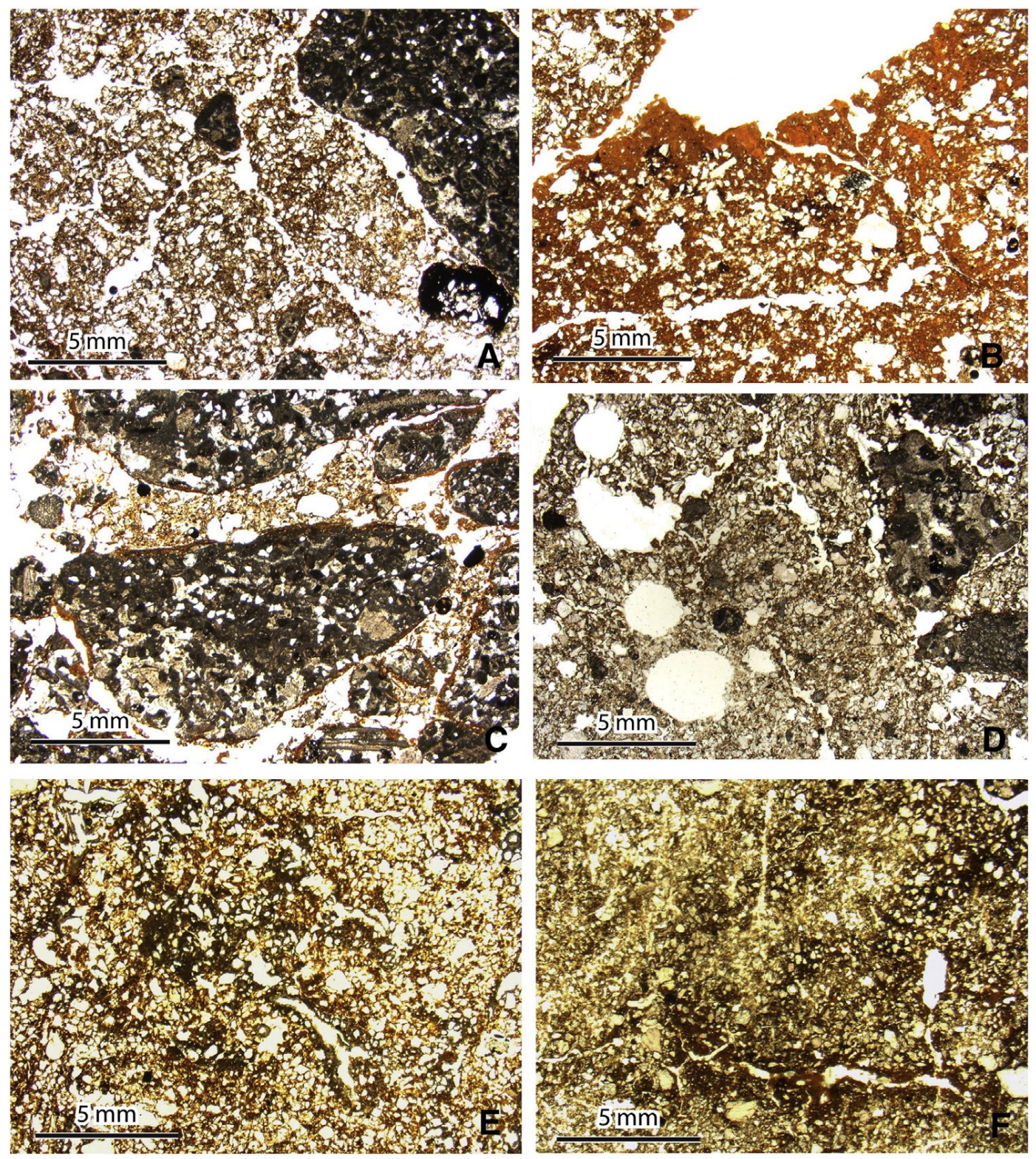

Fig. 7. Microfacies of the deposits: A - cambic Bw horizon (thin section 7); B - argic Bt horizon (thin section 6); C - silt cappings in the slope deposits (Dcm) (thin section 8); D - vesicular structure (Dcm) (thin section 9); E - decalcified sand with a biological porosity and brown silty clay intercalations (IIBg horizon) (thin section 3); F - decalcified sand with a biological porosity and brown clay illuviation (IIIBth horizon) (thin section 2). 


\subsubsection{Lithofacies of the lower sequence (cores SSIb, SS 2 and SS5)}

Three closely-spaced cores at the downslope end of the trench produced quite dissimilar profiles for the lower sequence (Fig. 2): SS2 and SS5 have a continuous, 60 and $35 \mathrm{~cm}$ thick, respectively, peat/gyttja level whereas SS1b produced no evidence of organic sediments (Fig. 8).

Peaty levels detected in the first two cores are overlain by a succession of sand, sorted fine gravel, and diamictic beds (Dmm) similar to those observed higher up in the sequence. These levels are interpreted as overland flow deposits and debris flows. The poor lateral extension of the coarsegrained lenses makes it difficult to correlate beds between the different cores.

The peaty levels are not uniform and the following stratigraphy can be distinguished in core SS2 core (from bottom to top), where these levels are thickest (Fig. 8):

(1) Grey alluvial sands whose mineral content is consistent with those from the Vézère (6.86 to 6.90 $\mathrm{m})$.

(2) Black homogeneous organic sand (6.82 to $6.86 \mathrm{~m})$ with a substantial mineral component. This unit appears dark in X-ray images.

(3) Dark grey organic silty-clay (gyttja) (6.42 to $6.82 \mathrm{~m}$ ). In thin section, this interval appears to be composed of alternating finegrained, poorly sorted beds and well-sorted fine sand/coarse silt laminae whose packing voids are filled with an orangebrown organic gel (Fig. 9A and B). Identifiable organic tissues are rare. Lighter coloured laminae rich in calcareous silt are visible in the upper part of this interval and correspond to $\mathrm{Ca} / \mathrm{Si}$ peaks in the ED-XRF profile. Indicators of detrital inputs ( $\mathrm{Zr}, \mathrm{Rb}$ ) do not show any significant changes (Fig. 10). As such, the carbonates are considered to be of biogenic origin (Charophyte remains, see §4.3.2) and/or correspond to precipitations of calcite crystals ("lake chalk") within the water column due to photosynthetic activity (Kelts and Hsü, 1978).

(4) Fibrous peat (6.32 to $6.42 \mathrm{~m}$ ) mainly composed of moss fragments (Fig. 9C). In thin section, this facies comprises compacted tissue remains almost totally lacking in a detrital fraction (Fig. 9D) and containing limited woody debris. This facies appears light on X-ray images and reflects the growth of almost exclusively moss vegetation.

(5) A bed of grey weakly organic calcareous silt (6.29 to $6.32 \mathrm{~m}$ ). 


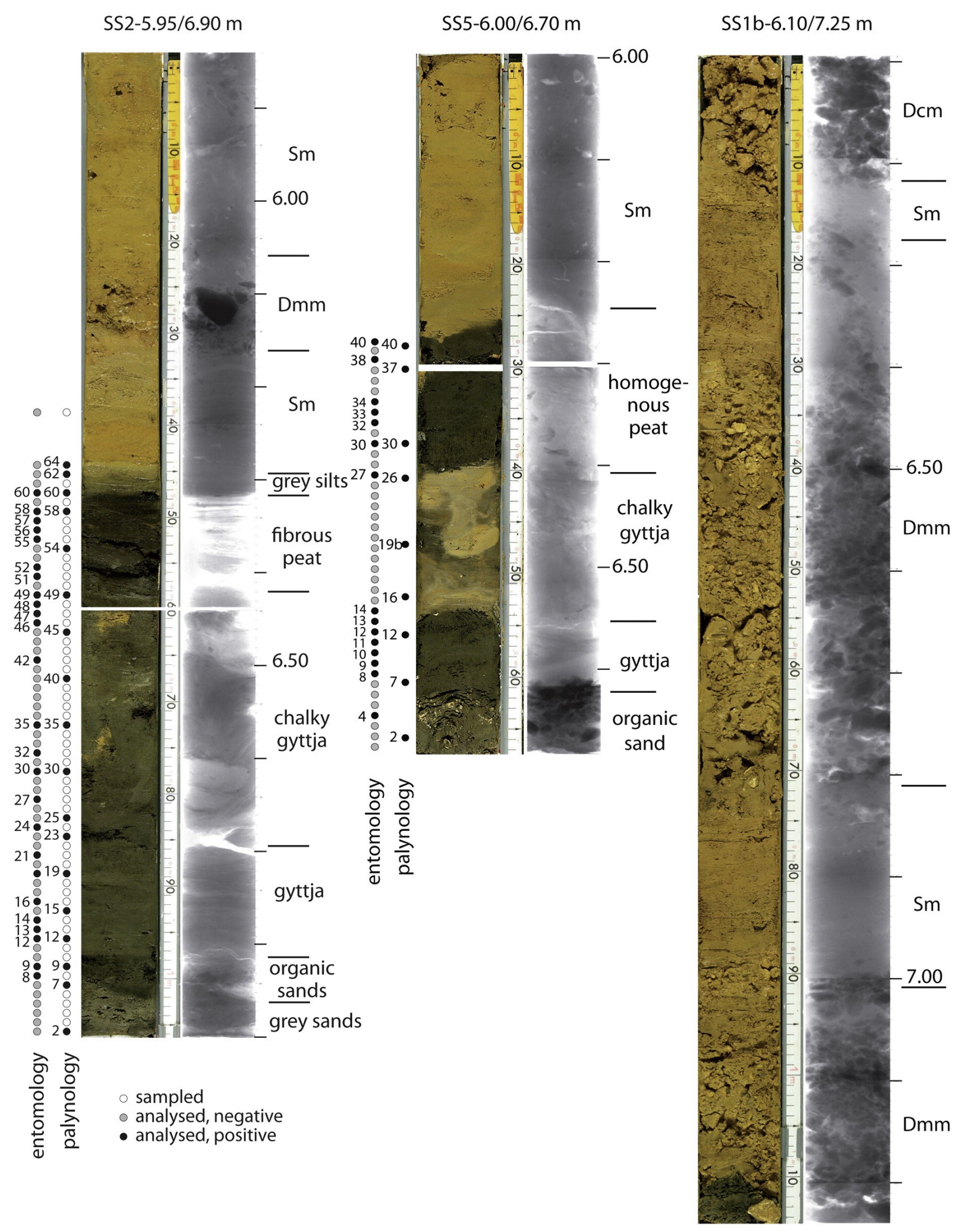

Fig. 8. Photo and RX image of cores SS2, SS5 and SS1b with location of the analyzed samples. Depths are in meters. 

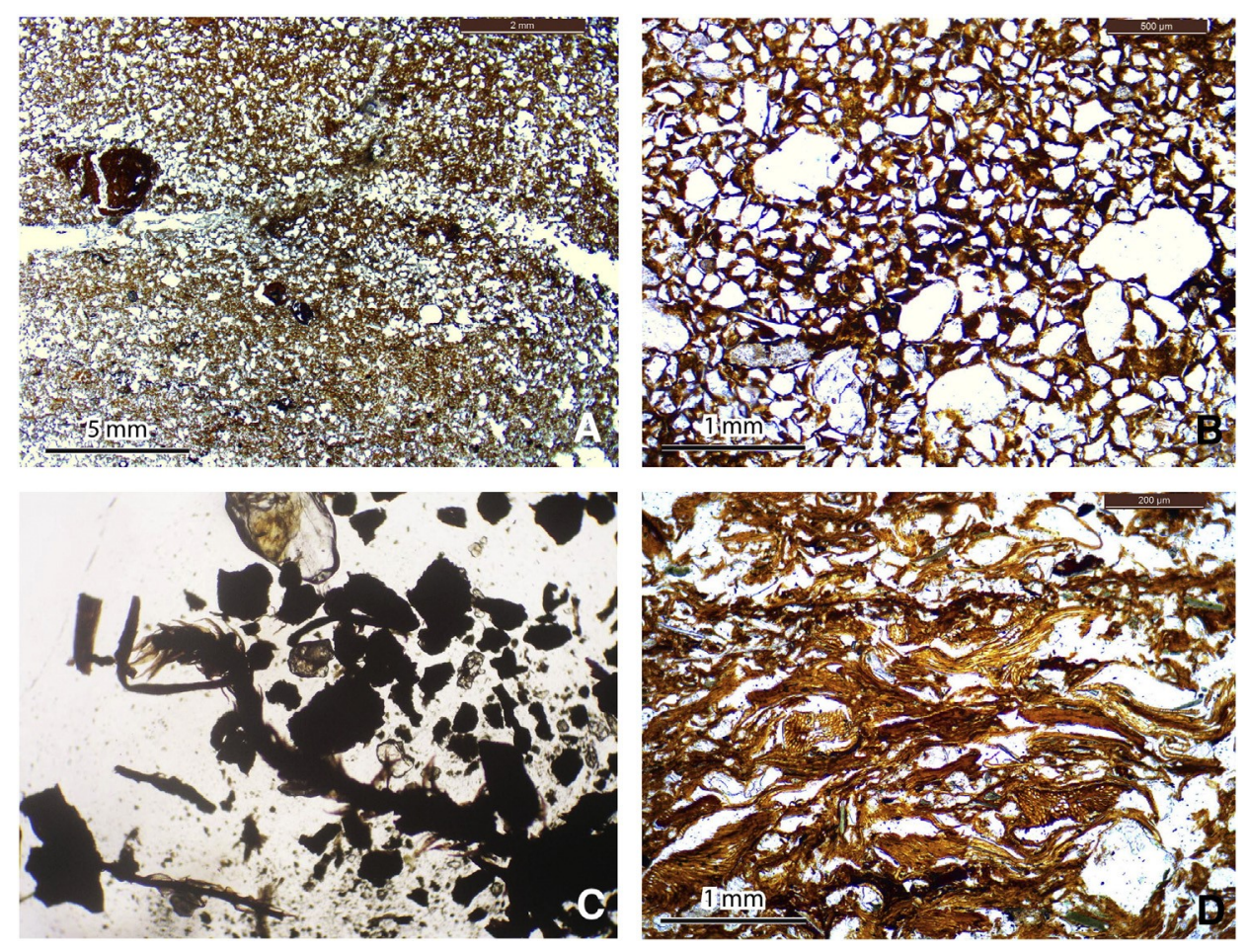

Fig. 9. Microfacies of the peat levels: A - bedded organic sandy silt deposits; B - fine sand bed with an amorphous organic matrix; $\mathrm{C}-$ moss fragments; $\mathrm{D}$ - compact accumulation of vegetal remains (mainly mosses).

\subsubsection{Geochemistry}

Thirty samples were taken from the trench, core SS2, the SC1, SC3 and SC4 geotechnical cores (campaign 2013), and from sediments outcroping around the site. These include (1) red clay (referred to here as "karst red clay") filling fissures in the $\mathrm{c} 4 \mathrm{~b}$ limestone exposed along the road leading to Lascaux Cave, (2) red clayey colluvium overlying the same limestone ("red colluvium "), (3) yellow sand outcroping on the plateau ("plateau sands"), (4) alluvial sand of the Vézère deposited by recent floods near Montignac ("Fz"), and (5) sand from an old alluvial terrace visible along the D704 road approximately $800 \mathrm{~m}$ from the site ("Fw"). Insoluble residues of the $\mathrm{c} 4 \mathrm{~b}$ limestone dissolved in acetic acid were also analyzed. Finally, the samples from cores SC1, SC3 and SC4 include (1) weathered, still cohesive c3c limestone, (2) noncohesive sand (both referred to as "weathered limestone"), (3) gravelly sand ("karst alluvium"), and (4) river alluvium ("Fx").

Multivariate analysis performed separately on the fine $(\mathrm{b} 63 \mu \mathrm{m})$ and sand fractions $(2 \mathrm{~mm}-63 \mu \mathrm{m})$. For the latter, the results showed (Fig. 11):

(1) The variance is mostly related to calcium $(\mathrm{Ca})$. The biplot first axis, therefore, opposes the limestone-rich detrital levels and the decalcified levels.

(2) The plateau sands, weathered limestone and red colluvium are heavily depleted in weatherable minerals $(\mathrm{Si}+\mathrm{Zr}+\mathrm{Ti}$ pole $)$ and are rich in iron oxides.

(3) The alluvial deposits of the Vézère (Fz, Fx, and to a lesser extant Fw) are richer in K-minerals, such as muscovite and $\mathrm{K}$-feldspar, compared to the other samples $(\mathrm{K}+\mathrm{Rb}$ pole, $\mathrm{Rb}$ substituting $\mathrm{K}$ in silicates, Salminen, 2005). The Fx sand from core SC3 has a higher calcium content than do recent flood deposits $(\mathrm{Fz})$ due to secondary $\mathrm{CaCO} 3$ precipitation. The composition of a level of gravelly sands (karst alluvium) collected from a depth of $14 \mathrm{~m}$ (i.e. about $5 \mathrm{~m}$ below the contact between Fx and the limestone bedrock) is significantly different from that of Fz, but is close to 
the weathered limestone. These sand infillings of karst conduits, therefore, derive from both weathered limestones and old alluvial gravel formations.

(4) The colluvial deposits are distributed between the pole plateau sands + karstic clay and the pole carbonates. This indicates that they correspond to a mixture of regolith material and fragments of the limestone substrate.

The biplot of the fine fraction reveals several differences with the sands. The main poles are the carbonates $(\mathrm{Ca}$, whose contribution to the overall variance is significantly lower than for the sand fraction, and $\mathrm{Sr}$, frequently substituting $\mathrm{Ca}$ in minerals) and iron oxides ( $\mathrm{Fe}+\mathrm{Cr}$, in substitution of $\mathrm{Fe}$, and As, often adsorbed on oxides, Salminen, 2005). Silicon (Si) is inversely correlated with $\mathrm{Zr}$ and Ti and is most likely mainly a component of clay minerals such as kaolinite or montmorillonite. The composition of the fine fraction of the slope deposits falls between those of the weathered limestone and the karst red clay and does not overlap with the alluvial deposits of the Vézère. This suggests a lack of any contribution due to flooding. Finally, the composition of the karst alluvium collected from a depth of $14 \mathrm{~m}$ resembles the weathered limestone. The high iron (Fe) and arsenic (As) content is likely related to the presence of sulfides precipitated in the alluvial deposits due to the activity of anaerobic bacteria in a phreatic context (pyrite: FeS2, arsenopyrite: FeAsS).

$\mathrm{The} \mathrm{Ca} / \mathrm{Si}$ ratio of the slope deposits in core SS2 (Fig. 10) displays erratic fluctuations that reflect stacked layers deposited by a wide range of processes (overland flow, debris flows, avalanches, solifluction). The middle part of the stratigraphy (2.90 to $5.45 \mathrm{~m}$ ), which comprises mainly decalcified silty sands, shows a strong geochemical homogeneity.

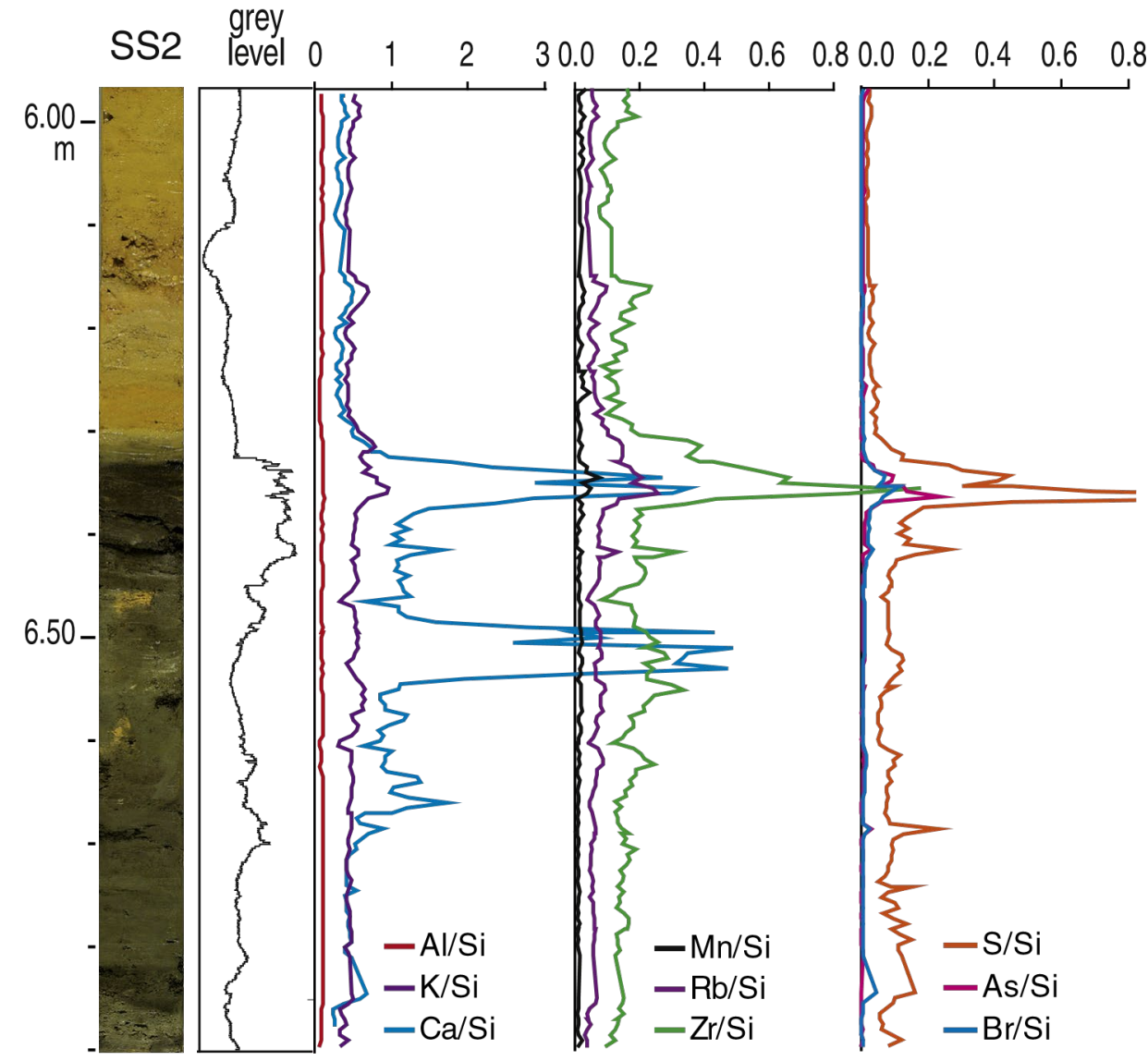

Fig. 10. Grey levels and evolution of some elemental ratios in core SS2. 


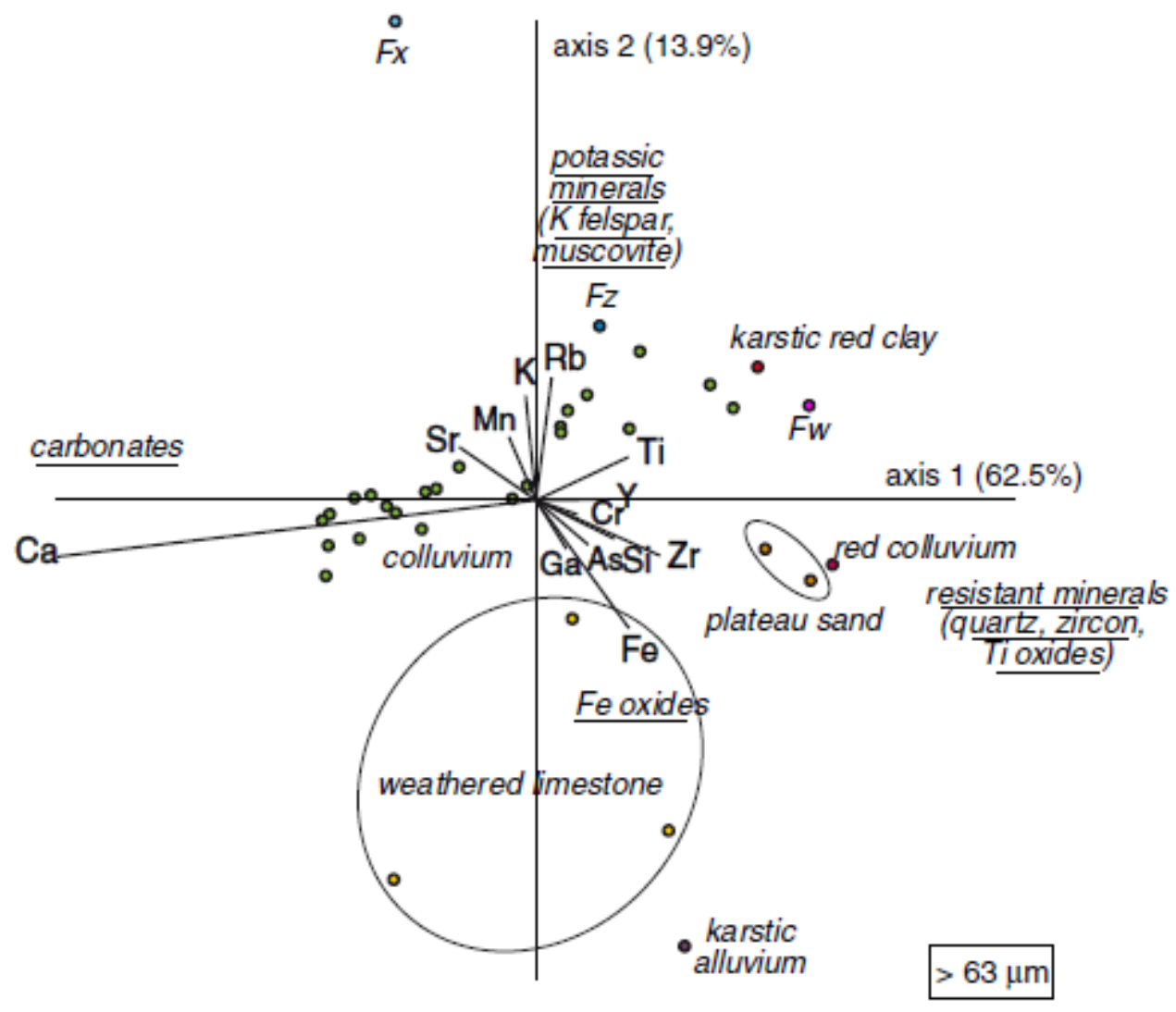

Fig. 11. Biplot of the chemical composition of the sediments, fraction $>63 \mu \mathrm{m}$.

\subsection{Chronological data}

Three ${ }^{14} \mathrm{C}$ dates obtained on charcoal fragments collected from the anthropogenic colluvium at the top of the sequence (Fig. 2), $1210 \pm 30$ BP (694-891 cal AD) and $1020 \pm 30$ BP (903-1147 cal AD) for the first generation of colluvium and $45 \pm 30 \mathrm{BP}(1694-1918 \mathrm{cal}$ AD) for the second generation (Table 1), indicate these units to have been deposited during medieval and modern periods.

Mousterian lithics found between depths of 3.2 and $4.4 \mathrm{~m}$ in finegrained colluvium in the downslope part of the trench (Fig. 2) suggest limited post-depositional displacement. Their presence indicates the lower part of the sequence to have been deposited no later than ca. $40 \mathrm{ka}$.

Three OSL dates on quartz were also obtained. The uppermost sample (OSL3) was taken from the wall of the trench at a depth of $3.0 \mathrm{~m}, 7 \mathrm{~cm}$ below the coarse-grained slope deposits (Fig. 2). This sample of decalcified sand produced an age of $49 \pm 7 \mathrm{ka}$, which corresponds to the first third of marine isotopic stage (MIS) 3. The second sample (SS2bis-615-620) taken from the sand immediately overlying the peat returned an age $(149 \pm 25 \mathrm{ka})$ inconsistent with the other radiometric dates. This is likely due to an abnormally low dose rate for this sample $\left(0.8 \mathrm{mGy} \mathrm{a}^{-1}\right)$ compared to that calculated for the other samples ( 2.3 to $\left.2.4 \mathrm{mGy} \mathrm{a}^{-1}\right)$. A possible explanation for the low dose rate may be the washing of the fine-grained fraction containing radioactive elements $(\mathrm{U}$, Th and $\mathrm{K}$ ) by pressurized water injected into the Shelby sampler to extract the core. Unlike the twin core SS2, the sands appeared soft and oversaturated. Insofar as geochemical data indicate the composition of the sands to be similar to that of sample OSL3, it can be assumed that the $\alpha, \beta$ and $\gamma$ dose rates of the two samples were originally comparable. Consequently, the age calculated for SS2bis-615-620 is close to $60 \mathrm{ka}$, or the end of MIS 4. Finally, a third date of $73 \pm 12$ ka obtained from the Vézère sands below the peat (SS2bis-685-690) 
shows alluvial sedimentation to have ceased during late MIS 5 (sub-stage 5a) or early MIS 4 (SánchezGoñi and Harrison, 2010).

\begin{tabular}{|c|c|c|c|c|c|c|}
\hline \multicolumn{7}{|l|}{ Radiocarbon } \\
\hline Sample & Lab. code & \multicolumn{2}{|l|}{ Age BP } & \pm & \multicolumn{2}{|c|}{ Age cal. AD $(2 \sigma)$} \\
\hline Montignac C1 & Poz-55940 & 1210 & 3 & & $694-89$ & \\
\hline Montignac C2 & Poz-55941 & 1020 & 3 & & $903-114$ & \\
\hline Montignac C4 & Poz-55942 & 45 & 3 & & 1694-191 & \\
\hline \multicolumn{7}{|c|}{ Optically stimulated luminescence } \\
\hline Sample & Dose rate ( $\mu \mathrm{Gy} / \mathrm{an})$ & \pm & De (Gy) & \pm & Age (ka) & \pm \\
\hline OSL-3 & 2354 & 83 & 116 & 14 & 49.3 & 7.3 \\
\hline SS2bis-615-625 & 844 & 9 & 139 & 20 & 149 & 25 \\
\hline SS2bis-615-625 & $\sim 2300$ & & & & $\sim 60$ & \\
\hline SS2bis-685-690 & 2484 & 62 & 182 & 26 & 73 & 14 \\
\hline
\end{tabular}

Table 1 Radiocarbon and OSL ages. Calibration of ${ }^{14} \mathrm{C}$ ages was made with Calib Rev. 6.1.0 and the IntCal09 curve.

\subsection{Palaeoecology}

\subsubsection{Pollen}

Apart from a few rare exceptions, the analyzed pollen material is considerably corroded. The high numbers of Cichorioideae and unidentifiable grains may be overrepresented in the pollen spectra due to their resistance to oxidation (Havinga, 1984). Mycelium and fungal spores are present throughout the peat deposits, with the concentration in samples 24 and 25 from core SS2 strongly suggesting a lowering of the water level accompanied by a deterioration of the pollen material.

The organic deposits from core SS2 provide evidence for the emergence of a more or less invasive sedge meadow and a reed bed bordering a perennial pond. Inputs from surrounding vegetation and offsite pollen connected to overland flow and natural pollen fallout were also identified (Fig. 12, Table SI_1). The presence of pondweed throughout the peat deposits attests to the presence of standing water. Apart for the occasional heather-type shrubs (Ericaceae), arboreal pollen is absent from the lowermost samples (Phase Mon. 1, samples 2 to 25: organic sand then gyttja). Given the abundant production and wide dispersion of pine pollen, their presence likely reflects either a remote location for this species or only limited numbers of trees. This is probably the same for birch. 


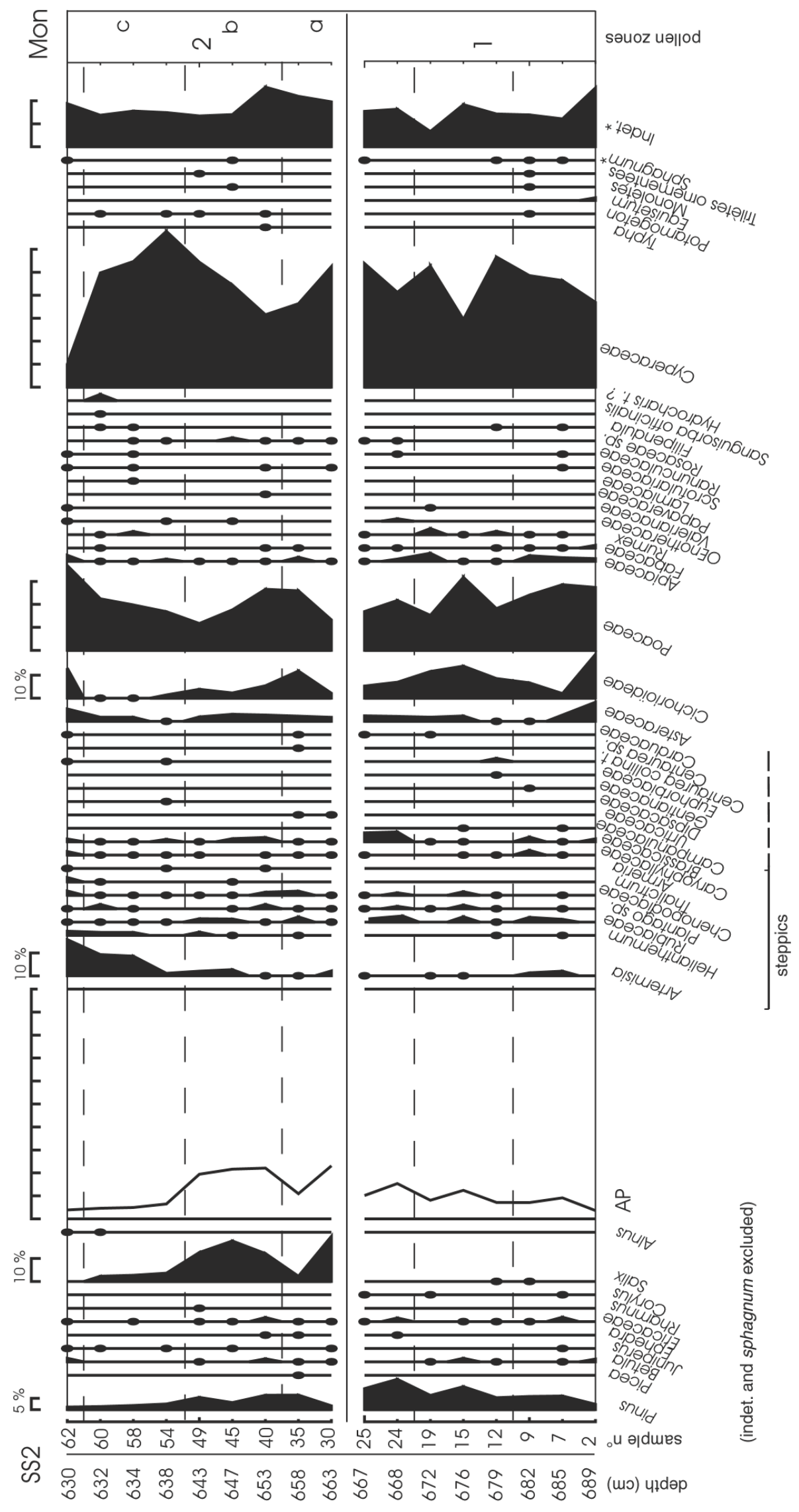

Fig. 12. Pollen diagram of the SS2 peat sequence (indetermined and Sphagnum excluded). 
The herbaceous layer is significantly heliophilous. The high pollen production of Poaceae and its wide dispersion suggests several of these taxa to reflect stational flora of well-drained areas around the pond while others come from a more distant steppe landscapes. Pollen rarely allows plants to be identified beyond the family level, which frequently comprises species with different ecological needs. The vast Brassicaceae family includes numerous hygrophilous plants, while Helianthemum attests to the existence of surrounding dry land.

The second phase sees the development of a willow stand on wet grounds without a significant change in vegetation (Mon. 2, samples 30 to 62: chalky gyttja and fibrous peat). A sedimentary hiatus concomitant with the onset of gyttja deposition does not allow the gradual arrival of this heliophilous pioneer tree species to be documented. During this phase, arboreal pollen (AP) reaches up to $24 \%$. The occasional presence of spruce, very resistant to cold, may also suited to peaty soils (Rameau et al., 1993). Macrofossils (see §4.3.2.) indicate an evolution towards an almost exclusive accumulation of mosses in the upper part of the sequence ( 6.32 to $6.42 \mathrm{~m}$ ). This change, however, was not detected in all pollen samples as only limited numbers of moss spores were recorded. This pattern may be connected to the poor preservation of the pollen material and the likelihood of moss spores having been destroyed by taphonomic processes.

The pollen spectrum of the grey silts at the top of the sequence reflects a steppe environment dominated by grasses. Trees are absent or extremely rare and AP decreases abruptly to only $8.6 \%$ in sample 54 and While phase Mon. 1 is almost entirely absent in core SS5 (Table SI_2), 3.8\% in sample 62. The development of Artemisia associated with Mon. 2 is thicker with a pollen signal that includes both typical wetland Helianthemum equally suggests a dry, cold steppe environment. species (willow, sedge meadow) as well those common on drier slopes (i.e. steppe taxa). The increased resolution in the off-site pollen signal may be due to greater sedimentary inputs from the slopes due to overland flow. This sequence can be correlated with sub-phases $2 a$ and $2 b$ of core SS2.

Plant cover was therefore primarily herbaceous, except for local willows and more distant or sparse pine and birch stands. The marshy meadow evolved away from the pond into a cold steppe populated by grasses and Artemisia. In such a context, the presence of more thermophilous taxa is more surprising. The sporadic hazel pollen, a pioneer mesophilous tree, in the two sequences suggests sunnier areas downslope. Hornbeam, a post-pioneer mesophilous species, is present both at the bottom and top of SS5. Finally, the well-preserved pollen (cytoplasmic membrane) in the uppermost peat represents pollution during coring.

\subsubsection{Plant macro-remains}

\subsubsection{Preservation.}

Excluding mosses, which are particularly abundant in samples 10, 17, 35, 36, 55, 56 and 59 of SS2, 267 macro-remains were recorded (Table SI_3). Macro-remains are represented by both wellpreserved and highly fragmented specimens, a pattern evident in each sample and for the same taxon. Sedge seeds, the family of plants best represented throughout the sequence, are heavily fragmented (70.4\%). Several other seeds are intact but are completely flattened. This is the case for the second best represented taxon, bladderwort (Utricularia sp.), identifiable by its typical curlicue cellular network (Fig. 13, $\mathrm{n}^{\circ} 13$ ). Conversely, the goosefoot (Chenopodium sp.) from sample 63 has a very different, much fresher aspect, with the still visible albumen behind the integument suggesting its introduction in the water used for coring.

\subsubsection{Taxonomic spectrum and palaeoecological reconstruction.}


Ten taxa were recorded (Fig. 14). Two, the yellow mignonette (Reseda lutea) and the small toadflax (Chaenorrhinum minus) were identified to species and two, Utricularia sp. and Papaver sp., to genus (Fig. 13, $\mathrm{n}^{\circ}$ 9). The remaining specimens were all identified at the family level: Characeae, Cyperaceae, Asteraceae (Fig. 13, n ${ }^{\circ}$ ), Caryophyllaceae (Fig. 13, n¹0), and Poaceae.

Utricularia (Fig. 13, $\left.\mathrm{n}^{\circ} 13\right)$ is particularly well represented $(\mathrm{n}=59)$ and a single gyrogonite from the aquatic alga Chara was identified in sample 6 (Fig. 13, $\mathrm{n}^{\circ} 12$ ). The presence of these taxa suggests the persistence of standing water throughout the deposition of the sequence.

Cyperaceae achenes (Fig. 13, $\mathrm{n}^{\circ} 1-5$ ) are difficult to distinguish from each other even when fresh. The fairly high representation of this family $(\mathrm{N}=115)$, of which many species are found around lakes, strongly suggests it to have formed part of the local plant community.

The yellow mignonette (Reseda lutea) (Fig. 13, $\mathrm{n}^{\circ} 8$ ) and the small toadflax (Chaenorrhinum minus) (Fig. 13, n7) grow in very different soils from those discussed above (Ellenberg, 1979). Reseda is currently found along roads, in fallows on dry slopes, preferably on limestone, while Chaenorrhinum grows in row crops, gardens and disturbed contexts (Lambinon et al., 2004). Plants growing on welldrained to dry grounds, more open in the case of Chaenorrhinum than for Reseda can, therefore, be imagined. These two taxa appear only in a limited number of samples in the lower part of the organic levels (samples 13 to 26 for Chaenorrhinum, 11 and 12 for Reseda).

Overall, a number of similarities with the pollen data can be noted, especially in the strong representation of sedges that probably formed a belt around the pond. The remains of bladderwort and charophytes attest to the presence of standing water. Cold climatic conditions suggested by the pollen spectra is partly the result of the tree taxa, which are not recorded among the macro-remains either because of their distance from the site (Pinus, Juniperus) or the fragility of their seeds (Salix, Betula).

Among the mosses, the common European species Drepanocladus aduncus (Hedw.) Warnst, Cratoneuron filicinum (Hedw.) Spruce var. fallax (Brid.) Roth, and Brachythecium cf. rutabulum (Hedw.) Schimp are all present. D. aduncus and C. filicinum are hygrophilous mosses that grow near ponds and rivers on calcareaous substrates. Moreover, the latter is known to occur on permanently wetland contexts. B. rutabulum colonizes a large variety of biotopes, including rocks, tree trunks, and temporarily wet ground. 


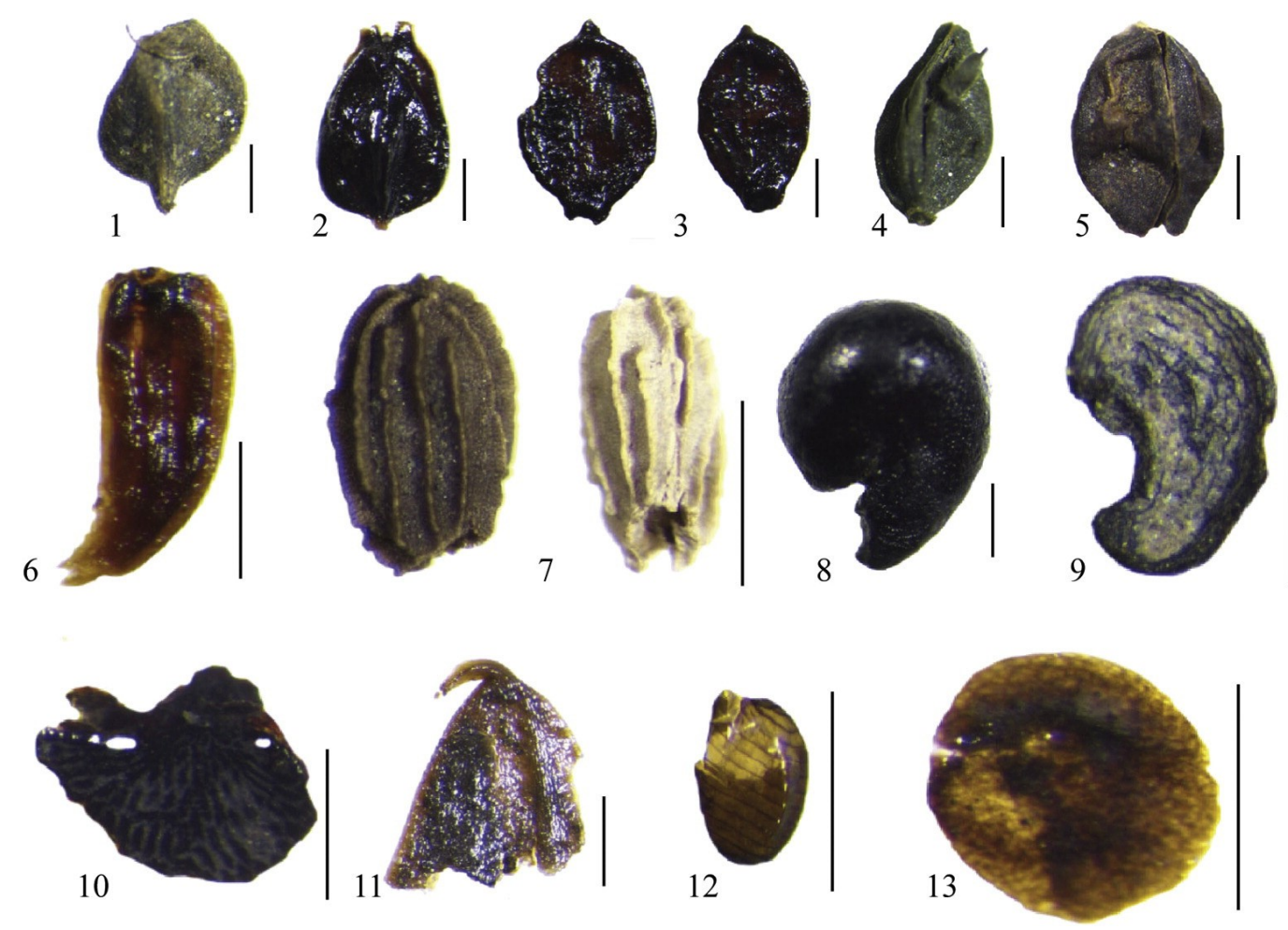

Fig. 13. Macro-remains. 1 to 5 - Cyperaceae (samples 1, 5, 12, 23 and 49); 6 - Asteraceae (sample 49); 7 Chaenorrhinum minus (sample 26); 8 - Reseda lutea (sample 20); 9 - Papaver sp. (sample 12); 10 - Caryophyllaceae (sample 32); 11 - indetermined (sample 6); 12 - Charophyte, gyrogonite (sample 7); 13 - Utricularia sp. (sample 10). Scale $=1 \mathrm{~mm}($ photos M.-F. D-S).

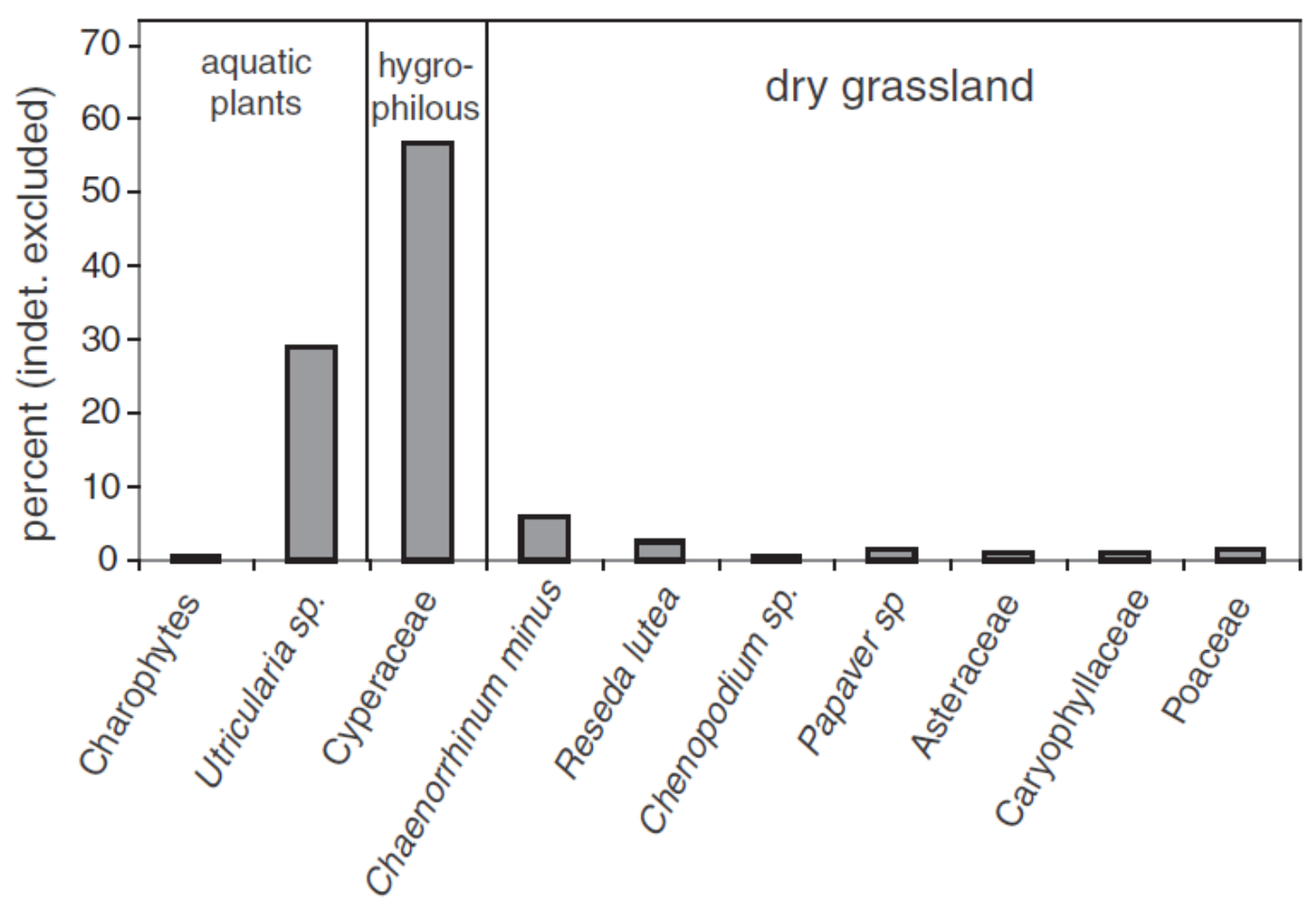

Fig. 14. Frequency of the taxa identified from macro-remains. 


\subsubsection{Beetles}

Beetles identified in the 111 samples are listed (Tables SI_4 to 6) as the minimum number of individuals in each sample for a particular taxon based on diagnostic elements of the exoskeleton. The assemblages are characterized by both low numbers of beetle fragments and limited taxonomic diversity. Many samples were entirely free of insect fragments; only 24 out of 67 samples contained beetle remains in SS2, 15 out of 43 in SS5. These two core samples produced 24 taxa and 18 taxa, respectively, with 13 taxa identified in "Montignac Trench 56/81.57". Only beetles were considered as the other insect orders are represented by rare unidentifiable fragments. The small size of the beetle assemblage, connected to unfavorable taphonomic conditions, precludes tracing changes in the sequence and the assemblage was therefore analyzed as a single sample.

\subsubsection{Beetle remains from SS2.}

Ground-dwelling predatory species Carabidae and Staphylinidae dominate (Table SI_4), with the former represented uniquely by hygrophilous species. Epaphius secalis occupies humid habitats, where it is found under dead leaves and plant debris, especially in humus-rich soils, humid forests, and meadows. This species is widespread in central Europe and Scandinavia as far as northern Norway. Epaphius rivularis inhabits peaty forests with birches, alders, willows and sedge grasses as well as Sphagnum bogs. In France, it is restricted to cold bogs in mountain contexts (Lecoq, 1990; Tronquet, 2014). Unlike the previous species, Pterostichus diligens is widely distributed throughout Europe, found in humid areas of lake edges and riverbanks as well as wet grasslands in both forest and open environments. This species is typical of oligotrophic and dystrophic lakes and peat bogs, often occurring under alder cover. The eurytopic species Pterostichus melanarius has much less stringent environmental requirements. Among rove beetles, only Anotylus rugosus was identified to species. Like the Hydrophilid Cercyon cf. tristis, it is associated with the vegetal litter around water sources. Aquatic beetles are only represented by Hydroporus sp.

The presence of byrrhids, Chrysomelidae and weevils suggest the existence of particular genus or species of plants. For example, most species of the genus Byrrhus are associated with mosses. Donacia and Plateumaris are large, impressive beetles typically found among plants found at the edges of ponds and rivers (Bordy et al., 2012). Present throughout Europe, Donacia clavipes is particularly interesting as this beetle depends on Phragmites that it consumes only as a larva, and on which it hangs when adult. The species complex Plateumaris discolor/ sericea lives mostly on the sedges Carex and Eriophorum, Caltha palustris, Sparganium, Menyanthes trifoliata.

Among the weevils, Notaris aethiops seems more polyphagous and lives on Scirpus, Typha, Carex, Poacaeae, Sparganium ramosum or even Iris pseudacorus. Its French distribution is limited, known only from lake shores in cold areas of the Massif Central. Although probably adapted to cold climates, its current fragmented distribution may also be a consequence of the human destruction of its natural habitats, namely peat bogs and swamps, as Notaris aethiops has been found in Holocene contexts in southern England (David Smith, pers. Com.).

\subsubsection{Beetle remains from SS5.}

Dyschiriodes globosus is an eurytopic species capable of living in all types of wet soils found at the edges of lakes and rivers sparsely covered by herbaceous plants (Table SI_5). Widely distributed across Europe, the ecology of these two species of riparian Philochthus is quite similar; they colonize the edges of lakes, rivers and woodland ponds, where they live among the mosses and dead leaves. Coelostoma orbiculare is also associated with plant debris accumulated at the edges of European waterways. The presence of Eucnecosum brachypterum is much more significant in terms of climate. 
This rove beetle, which is currently extinct in France, occupies a vast territory, particularly cold, alpine and subalpine regions of the British Isles, northern Scandinavia, Central Europe from Germany to Russia, the Alps (but not in the French Alps), Transylvania, Bulgaria, Caucasus, Siberia, northern Mongolia, and North America (Zanetti, 1987). This species is associated with another mountain beetle, Amidorus obscurus. This coprophagous beetle is extremely common in mountain pastures that are home to both wild and domestic herds in central Europe, the Alps, the Apennines, the Balkans, Minor Asia, and the Caucasus (Paulian and Baraud, 1982). Its presence at Lascaux is quite unexpected and suggests both the presence of meadows and a much colder climatic conditions than currently experienced by the region.

\subsubsection{Beetle remains from "Montignac Trench 56/81.57" sample.}

This beetle-rich assemblage is comparable with those from the other samples (Table SI_6). With that said, Cymindis vaporariorum was only recorded in this sample, an occurrence which is particularly interesting in palaeoecological terms. In France, this species currently lives in the Alps, Pyrenees, and parts of the Massif Central, where it is found at high altitudes under stones (Bonadona, 1971). Lindroth (1985-1986) described its habitat in Scandinavia as, "more or less dry, sandy or gravelly, rarely peaty soil with sparse vegetation of Calluna, Empetrum, grasses, Cladonia, etc., both on open heaths and in thin pine forest". Aquatic beetles are represented by a single example of Hydroporus sp. The very rare rove beetle Acidota crenata lives in vegetal litter in cold regions and may now be extinct in the region. Alongside Olophrum fuscum, which has a very similar ecology, these two species are much more prevalent in cold regions of Europe and therefore indicate colder climatic conditions than today at Lascaux. A final rove beetle, Euaesthetus laeviusculus, a tiny species found in mosses and the edges of ponds, was also recorded in this sample.

\subsubsection{Palaeoclimate reconstruction from beetle assemblages.}

A climate reconstruction using the mutual climatic range method (Atkinson et al., 1986) and the software BugsCEP (Bugs Coleopteran Ecology Package, Buckland and Buckland, 2006) was built from all the identified taxa $(\mathrm{N}=12)$ contained in the MCR database (Dyschiriodes globosus, Epaphius secalis, Epaphius rivularis, Pterostichus diligens, Pterostichus melanarius, Cymindis vaporariorum, Anotylus rugosus, Eucnecosum brachypterum, Acidota crenata, Olophrum fuscum, Euaesthetus laeviusculus, and Coelostoma orbiculare). The results are as follows:

TMax (average temperature of the warmest month) $=15^{\circ} \mathrm{C}$ to $16^{\circ} \mathrm{C}$.

TMin (average temperature of the coldest month) $=-12{ }^{\circ} \mathrm{C}$ to $4{ }^{\circ} \mathrm{C}$.

TRange $=12{ }^{\circ} \mathrm{C}$ to $27^{\circ} \mathrm{C}$. Overlap $=100$.

This model suggests temperatures to have been 5 to $6^{\circ} \mathrm{C}$ and $1.5^{\circ}$ to $17.5^{\circ}$ colder than current conditions in terms of TMax and Tmin, respectively. By comparison, Bergen (Norway) currently experiences TMax of $15{ }^{\circ} \mathrm{C}$ and Tmin of $1.3{ }^{\circ} \mathrm{C}$ (http://climatedata.e-monsite.com), which are very close to the reconstructed temperatures at Lascaux, at least for TMax. TMin values are usually the least significant, as the calculated range is much broader than for Tmax. In fact, the MCR is less precise for low temperatures due to the lower sensitivity of insects during winter months when they hibernate or experience diapause compared to the more active summer months for most beetle species (reproduction, development). This confirms the general impression provided by the identified taxa of 
a cold fauna that nevertheless differs from the very specific, cold arctic steppe assemblages of most of the Weichselian Glacial (Ponel, 1995).

Comparison with La Grande Pile record (Ponel, 1995) shows TMax values for Lascaux to fall between those of the final interstadials of MIS 5 and cold maximum of MIS 4. They are also clearly lower than temperatures reconstructed for MIS 5e (Eemian) and higher than those that prevailed during most of the Weichselian Glacial. Several relatively temperate assemblages identified within MIS 4, such as sample 23 of La Grande Pile, which is attributed to the Ognon interstadial complex (Helmens, 2014), are however quite close. In terms of the beetle assemblages, these warm events are comparable to the temperate climate episodes of early MIS 3 described by Coope and Angus (1975).

\section{Archaeology}

Sixteen lithic objects were collected from a depth of between 3.2 and $4.4 \mathrm{~m}$ during excavations in the downslope section of the trench (Fig. 2): a unipolar core on a small block of local Senonian flint, an éclat débordant that was likely detached from centripetal Levallois core, and several bifacial shaping flakes. Any precise chrono-cultural attribution is impossible due to the lack of tools, bifaces or more diagnostic core types. Based on associated OSL dates on the sediments, the Middle Palaeolithic occupation likely dates to MIS 3.

\section{Discussion}

The main results obtained for this thick sequence of peat and slope deposits overlying the alluvial terrace of the Vézère can be summarized as follows:

(1) A series of numerical dates demonstrates the peats and slope deposits to be of Weichselian age and cover the whole glacial period. The OSL age obtained on sands filling a paleochannel of the Vézère and underlying the peat place them to the Early Glacial ( $73 \mathrm{ka}$, i.e. late MIS 5 - beginning of MIS 4). Finally, the underlying alluvial terrace does not date to the Holocene as indicated on the 1:50,000 geological map.

(2) Peat developed locally in the Early Glacial palaeochannel within depressions subjected to karst sinking (i.e. dolines), a relatively common pattern with the limestone substrates in southwest France and recently described in the Dordogne Valley for the early Holocene (Bertran et al., 2013). The combination of geotechnical data and electrical tomography profiles clearly indicate doline formation to be primarily connected to a large in situ karst system developed in the Turonian limestone. Sandy units with diffuse limits may correspond to weathered limestone without volume loss ("fantomization" or "rock ghost" formation, Quinif, 2010; Dubois et al., 2011) in a phreatic context, whereas sandy clays and fine gravel may originate from alluvial deposits infilling open karst conduits. The in situ alteration of the limestone is further supported by a gradual transition between hard limestone and loose sands connected primarily to the extensive dissolution of the limestone cement and by the lack of lateral continuity of the sand levels revealed by the geotechnical data. River incision and the subsequent emergence of a hydraulic gradient between the terrace and the new Weichselian river bed probably reactivated the karst system. The accumulation of organic matter in the dolines and the concomitant production of organic acids may also have promoted karstification.

(3) The peat levels reveal an evolution of the depositional environments over time. Initially characterized by a lacustrine accumulation of sand and organic detritus, the site witnessed a phase of chalky gyttja sedimentation before the development of fen peat. A fen-like context rather than a true bog is suggested by the affinity of the identified mosses for hard water. The emergence of a 
pond followed by its progressive filling by terrigenous inputs and organic matter produced by the aquatic vegetation most likely drove the evolution of environmental conditions. OSL ages obtained immediately above and below these levels broadly place their formation to the end of MIS 5 and MIS 4 (ca. 73-60 ka). Several arguments suggest, however, that the peat formed relatively quickly, probably over a considerably shorter period than the $13 \mathrm{ka}$ indicated by the averaged OSL ages. First, the small size of the pond as indicated by the limited extension of the peat deposits implies a small volume available for the accumulation of sediment and organic matter and, therefore, rapid filling. Dolines of Lateglacial or Holocene age in palaeochannels of the Dordogne River produced peaty accumulations of similar thickness. The formation of these deposits has been estimated to require between 0.5 and $2 \mathrm{ka}$ based on radiocarbon dates (Bertran et al., 2009, 2013). Secondly, as plant communities respond quickly to climatic fluctuations, the homogeneity of the pollen spectra equally suggests a rapid sedimentation that did not span several stadials and interstadials (see Sánchez-Goñi et al., 2013, for the last glacial-interglacial transition in southwest France).

(4) Although scarce, plant macro-remains document the local environment around the fen. The bladderwort (Utricularia sp.) and the charophytes indicate the presence of a pond during the major portion of organic sedimentation, while the abundant sedge seeds attest to the development of awreath of hygrophylous plants. Several taxa, such as the yellow mignonette (Reseda lutea), small toadflax (Chaenorrhinum minus), Asteraceae and Poaceae, suggest the proximity of dry grasslands, probably on the slopes overlooking the site.

(5) Palynological analyses show that, with rare exceptions, corrosion of the pollen only significantly impacted the representivity of the pollen spectra in a limited number of samples. Fluctuations in hygrophilous herbs possibly reveal small variations in the water level of the marshy depression. The initially mainly herbaceous plant cover was subsequently colonized by local willow stands, with arboreal species almost completely absent in the more distant landscape. The low frequency of tree pollen likely to feature a boreal forest, such as pine and birch, supposes distant sources and, most probably, rare individuals scattered over wide grassy expanses. This steppe vegetation would have accompanied cold and dry environmental conditions similar to those reconstructed for the coldest periods of the Lateglacial. In this largely open landscape, Corylus, a mesophilous taxon, would represent either the persistence of more temperate (MIS 5) environmental conditions in sheltered and sunny refuges or reworked material introduced from the surrounding soils. The overall pollen spectrum portrays no clear contrasts in terms of pollen zonation and thus does not record obvious changes in the local environment apart from the uppermost grey silt layer. These 2 to $3 \mathrm{~cm}$ thick deposits mark the disappearance of swamp vegetation together with the development of a treeless, sagebrush and grass dominated steppe landscape. This event could mark a shift from cold to much more rigorous climatic conditions. In this respect, the documented sequence can be correlated with an interstadial within a glacial phase. Overall, the Lascaux 4 record shares several similarities with other French MIS 4 environmental records, particularly phase 12 documented at La Grande Pile (Woillard and Mook, 1982), phase 7 of La Grande Pile XX (de Beaulieu and Reille, 1992), and phases G-H of the Les Echets marsh (de Beaulieu and Reille, 1984).

(6) Despite the limited number of beetle remains recovered from the peat deposits and discontinuous record due to taphonomic issues, the assemblages nevertheless portrays clear trends. They do not allow identifying any clear environmental change over the period covered by the sequence, but provide an overall picture of a small lake or fen in a largely open environment (Fig. 15). In this respect, despite several beetle species seeming to show a preference for shady banks, there is no 
clear indication of the presence of trees like wood-boring or (sapro-)xylophagous beetles. Beetle species indicative of herbaceous vegetation provide evidence for hygrophilous plants such as sedges. Phragmites is clearly indicated by a monophagous Donacia species. Various beetle species suggest mosses to have been abundant on or around the site. In terms of climate, indicators of colder climatic conditions than currently experienced by southwest France are abundant (i.e. Epaphius rivularis, Cymindis vaporariorum, Eucnecosum brachypterum, Acidota crenata, Amidorus obscurus, and Notaris aethiops). Most are typical stadial species well documented from Last Glacial and Lateglacial contexts, all of which are present in "periglacial" deposits on the British Isles as well as in France (Ponel, 1995). Many of these species still occur in France, but only in mountains or in rare relict places. However, the absence of the most "cryophilous" species, such as Helophorus glacialis, reveal milder climatic conditions and the absence of snow covered ground in the summer. In this respect, comparisons with the entomozones GP-A7a and GP-A7b (Pleniglacial) described by Ponel (1995) at La Grande Pile is instructive as the coldest taxa found in this sequence are absent at Lascaux. Temperatures reconstructed by the mutual climatic range method suggest summer and winter temperatures to have been 5 to $6^{\circ} \mathrm{C}$ and 1.5 to $17.5^{\circ} \mathrm{C}$ lower, respectively, than currently experienced. Finally, the preferred stratigraphic distribution of "cold" species at both the bottom and the top of the peaty levels suggests that deposition was preceded and followed by more severe climatic conditions.

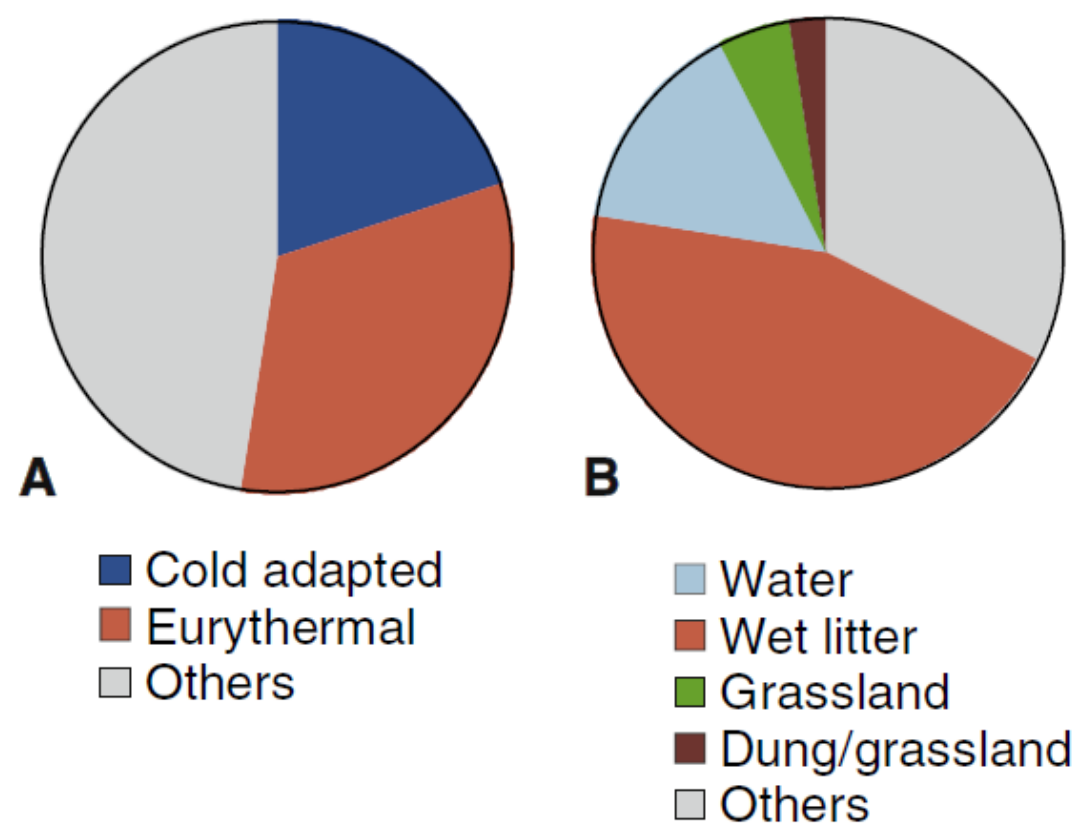

Fig. 15. Frequency of taxa grouped by thermal (A) and ecological (B) affinities. Cold-adapted taxa: A. crenata, A. obscurus, C. vaporariorum, E. rivularis, E. secalis, E. brachypterum, N. aethiops, O. fuscum; eurythermal taxa: A. rugosus, C. cf. tristis, C. orbiculare, D. clavipes, D. globosus, E. laeviusculus, O. rugifrons, P. biguttalus, P. cf. guttula, P. discolour, P. cornutus, P. diligens, P. melanarius; water: C. orbiculare, D. clavipes, Donacia/Plateumaris sp., Hydroporus sp., N. aethiops, P. discolour; wet litter: A. crenata, Agonum sp., A. rugosus, C. cf. tristis, D. globosus, E. rivularis, E. secalis, E. laeviusculus, E. brachypterum, Lathrobium sp., O. fuscum, P. cf. biguttatus, P. cf. guttula, P. cf. cornutus, P. diligens, P. melanarius, Ptomaphagus sp., Stenus sp.; grassland: C. vaporariorum, O. rugifrons; dung/grassland: A. obscurus.

(7) The OSL dates alongside with both the pollen and beetle assemblages indicate the peat deposits to have most likely formed during the Ognon II interstadial (i.e. GI-19.2 between 70.5 and 72.5 ka, Rasmussen et al., 2014). At La Grande Pile and Les Echets (de Beaulieu and Reille, 1992, 
1994), this interstadial appears as an almost treeless phase marked only by a slight increase in Pinus and Betula and the sporadic occurrence of Picea (zone $\mathrm{H}$ of Les Echets). In the Bay of Biscay, however, a weak development of the Atlantic forest (Quercus $=5.5 \%$ ) is recorded in core MD042845 (Sánchez-Goñi et al., 2013) and may reflect pollen inputs from remote refugia. The 200 to 400 year-long GI-19.1 (ca. $69.5 \mathrm{ka}$ ) and GI-18 (64 ka) interstadials are thought to have been to short to have supported for karst reactivation and lake filling. These phases are also not recorded in the above-mentioned pollen sequences. A herbaceous landscape is in agreement with the humic (steppe) soils typical of the Ognon interstadials in the loess record of northern France (Antoine et al., 2003). These highly productive steppe soils sustained a dense population of herbivorous mammals and are coincident with the greatest number of Middle Palaeolithic site in the region (Locht et al., 2015).

The peats were buried and then partially eroded by a thick sequence of slope deposits reflecting increased erosion and debris redistribution on the slopes during the Weichselian. Core SS2 and the lithostratigraphy exposed in the trench provide evidence for three phases of deposition. The lowermost sandy colluvial strata separated by coarser-grained debris flow units are overlain by homogeneous colluvial sands and boreal palaeosols. Finally, predominantly coarse-grained calcareous units with intercalated sandy levels were deposited by different sedimentary dynamics (overland flow, debris flows, snow avalanches, solifluction). This type of sequence is likely to have a climatic control and, at a first glance, may parallel low frequency climate changes during the glacial period. Accordingly, the lower coarse-grained unit OSL-dated to ca. 60 ka would correspond to late MIS 4, while the intermediate sands and palaeosols stratigraphically underlying an OSL age of ca. $49 \mathrm{ka}$ would correspond to the first half of MIS 3. Finally, the upper coarsegrained unit would date to the end of MIS 3 and MIS 2. The periglacial slope processes responsible for the deposition of the upper unit are responsible for a significant increase in downslope progression of the coarse-grained calcareous lithofacies.

(8) The palaeosols that developed in the middle part of the sequence are characterized by a Bth horizon of a greyzem overlain by a cambic Bg horizon formed in sandy colluvium. This soil complex has never been described before in southwest France. Typical of boreal contexts, the greyzem probably formed under forest cover and has an equivalent in the loess sequences of northern France (the "Saint Acheul-Villiers-Adam soil complex," Antoine et al., 2003; Locht et al., 2003) and Belgium (the "sol des Vaux," Haesaerts et al., 1999). At Villiers-Adam in the Paris Basin, Locht et al. (2003) described a lower, "brown boreal soil" marked by loess decalcification, strong bioturbation, illuviation, and redox phenomena (ferro-manganic nodules). This horizon is overlain by a second, more humic one described as an "arctic meadow soil" with a freeze-thaw (platy) structure and associated with luminescence ages between 50 and $35 \mathrm{ka}$. Although several differences between the Lascaux palaeosols and those documented at Villiers-Adam are evident and may reflect the role of the nature of sediment, site conditions such as local vegetation and drainage, and the diagenetic degradation of the organic components, these are likely equivalent and constitute a benchmark level for the Middle Pleniglacial.

(9) A small Middle Palaeolithic lithic assemblage (16 pieces), including bifacial thinning flakes, collected in and above the soil complex is too small to be assigned to a particular techno-complex and may represent one or several MIS 3 occupations.

(10) The calcareous slope deposits are weathered and affected by a luvisol. Soil development indicates the slope to have been stabilized by vegetation at the beginning of the Holocene or during the Lateglacial. The soil was then heavily truncated by historic period agricultural practices represented by two successive episodes of terracing. Radiocarbon dates obtained on charcoal place 
the oldest terraces to the early medieval period, whereas the most recent date to sometime between the 18th and 20th century.

\section{Conclusions}

The study of the thick sequence of peat and slope deposits discovered at the foot of the Lascaux hill sheds new light on the physical and biological palaeoenvironments of southwest France during the Last Glaciation, particularly MIS 4 . The $0.6 \mathrm{~m}$ thick peat levels at the bottom of the sequence record the progressive filling of a small pond in a karst context. The combination of palynological and entomological data with the OSL dates places these levels with a relatively high degree of confidence to the Ognon II interstadial (ca. 70-72 ka). Palaeoenvironmental data indicate a predominantly steppe landscape with almost no trees, except for willow stands in the vicinity of the pond. Although the study site is located in southern France, the reconstructed landscape does not differ significantly from that described for Ognon II interstadial in more northern sites such as La Grande Pile and Les Echets. With that said, no increase in arboreal pollen associated with the expansion of Atlantic forest as recorded in MD04-2845 core in the Bay of Biscay was identified. This landscape, which was colder than today, inhibited intense erosion of the surrounding slopes, unlike during the following glacial period. Unfortunately, the lack of organic matter precludes a more detailed reconstruction of palaeoenvironmental conditions contemporaneous with the occupation of Lascaux cave. While slope sedimentation shows MIS3 and MIS2 to have experienced periglacial climatic conditions, millennial scale changes in the local landscape are impossible to trace with any precision.

The Lascaux sequence appears as reference for the chronostratigraphy of the Last Glacial in southwest France, a period that remains poorly documented in open-air contexts. Insofar as Pleistocene organic deposits favorable for preserving detailed palaeoecological information are rare in the Aquitaine Basin, new multidisciplinary studies of similar small peat sequences should gradually shed new light on continental glacial environments in the region.

\section{Acknowledgements}

We acknowledge all the people who contributed to field work and laboratory analyses, particularly Maryse Alvitre, Isabelle Billy, Thibaut Guékié, Eric Lebraud, Philippe Malaurent, Philippe Poirier, Thierry Theato, Shan Xu and Jean-Hervé Yvinec. The Service Régional de l'Archéologie d'Aquitaine and the Conseil Général de la Dordogne are sincerely thanked for their help. We are also grateful to two anonymous referees for their constructive comments. B. Gravina made significant improvement of the language.

\section{References}

Aitchison, J., Greenacre, M., 2002. Biplots of compositional data. Appl. Stat. 51 (4), 375-392.

Andrieu, V., Eicher, U., Reille, M., 1993. The end of the last pleniglacial in the Pyrenees (France): pollen-analytical, isotopic and radiometric data. Comptes-Rendus de l'Académie des Sciences de Paris 316, série 2, pp. 245-250.

Antoine, P., Catt, J., Lautridou, J.P., Sommé, J., 2003. The loess and coversands of northern France and southern England. J. Quat. Sci. 18 (3-4), 309-318.

Atkinson, T.C., Briffa, K.R., Coope, G.R., Joachim, J.M., Perry, D.W., 1986. Climatic calibration of coleopteran data. In: Berglund, B.E. (Ed.), Handbook of Holocene Palaeoecology and Palaeohydrology. Wiley, Chichester, pp. 851-858.

Ballantyne, C.K., Harris, C., 1994. The periglaciation of Great Britain. Cambridge University Press, Cambridge (330 pp.). 
de Beaulieu, J.-L., Reille, M., 1984. The pollen sequence of Les Echets (France): a new element for the chronology of the Upper Pleistocene. Géog. Phys. Quatern. XXXVIII (1), 3-9.

de Beaulieu, J.-L., Reille, M., 1992. The last climatic cycle at La Grande Pile (Vosges, France). A new pollen profile. Quat. Sci. Rev. 11, 431-438.

de Beaulieu, J.-L., Andrieu-Ponel, V., Reille, M., Grüger, E., Tzedakis, P.C., Svobodova, H., 2001. An attempt at correlation between the Velay pollen sequence and the Middle Pleistocene stratigraphy from Central Europe. Quat. Sci. Rev. 20, 1593-1602.

Benn, D.I., 1994. Fabric shape and the interpretation of sedimentary fabric data. J. Sediment. Res. A64 (4), 910-915.

Bertran, P., Hétu, B., Texier, J.P., Van Steijn, H., 1997. Fabric characteristics of slope deposits. Sedimentology 44, 1-16.

Bertran, P., Texier, J.P., 1999. Facies and microfacies of slope deposits. Catena 35, 99-121.

Bertran, P., Allenet, G., Fourbouley, C., Leroyer, C., Limondin-Lozouet, N., Maazouzi, Z., Madelaine, S., Perrière, J., Ponel, P., Casagrande, F., Detrain, L., 2009. Paléoenvironnements tardiglaciaires en Aquitaine: la séquence alluviale de La Brunetière. Quaternaire 20 (2), 161-193.

Bertran, P., Frouin, M., Mercier, N., Naessens, F., Prodéo, F., Queffelec, A., Sirieix, C., Sitzia, L., 2013. Architecture of the lower terraces and evolution of the Dordogne River at Bergerac (southwest France) during the last glacial-interglacial cycle. J. Quat. Sci. http://dx.doi.org/10.1002/jqs.2656.

Blair, T.C., McPherson, J.G., 1998. Recent debris-flow processes and resultant form and facies of the Dolomite alluvial fan, Owens Valley, California. J. Sediment. Res. 68 (5), 800-818.

Blikra, L.H., Nemec, W., 1998. Postglacial colluvium in western Norway: depositional processes, facies and palaeoclimatic record. Sedimentology 45, 909-959.

Bonadona, P., 1971. Catalogue des Coléoptères Carabiques de France. Nouvelle Revue d'Entomologie (Supplément, 177 pp.).

Bordy, B., Doguet, S., Debreuil, M., 2012. Les Donaciinae de France (Coleoptera, Chrysomelidae). Rutilans \& Magellanes (92 pp.).

Buckland, P.I., Buckland, P.C., 2006. Bugs Coleopteran Ecology Package (Versions: BugsCEP v7.63; Bugsdata v8.01; BugsMCR v2.02; BugStats v1.22). Downloaded/CDROM: 1/07/ 2014 www.bugscep.com.

Bullock, P., Fedoroff, N., Jongerius, A., Stoops, G., Tursina, T., Babel, U., 1985. Handbook for Soil Thin Section Description. Waine Research Publications, Wolverhampton (152 pp.).

Bronger, A., 1978. Climatic sequences of steppe soils from eastern Europe and the USA with emphasis on the genesis of the 'argillic horizon'. Catena 5, 33-51.

Coope, G.R., 1986. Coleoptera analysis. In: Berglund, B.E. (Ed.), Handbook of Holocene Palaeoecology and Palaeohydrology. Wiley, Chichester, pp. 703-713.

Coope, G.R., Angus, R.B., 1975. An ecological study of a temperate interlude in the middle of the last glaciation, based on fossil Coleoptera from Isleworth, Middlesex. J. Anim. Ecol. 44, 365391.

Dubois, C., Lans, B., Kaufmann, O., Maire, R., Quinif, Y., 2011. Karstification de type fantômes de roche en Entre-deux-Mers (Gironde, France): implications en karstogenèse et morphologie karstique. Karstologia 57, 19-27.

Durand, N., Monger, H.C., Canti, M.G., 2010. Calcium carbonate features. In: Stoops, G., Marcelino, V., et Mees, F. (Eds.), Interpretation of Micromorphological Features of Soils and Regoliths. Elsevier, pp. 149-194.

Ellenberg, H., 1979. Zeigerwerte der Gefäßpflanzen Mitteleuropas. Göttingen (106 pp.). 
FAO-WRB, 2006. World Reference Base for Soil Resources. World Soil Resources Reports 103. Food and Agriculture Organization of the United Nations, Rome (128 pp.).

Fauna Europaea, 2011. Fauna Europaea version 2.4. http://www.faunaeur.org.

Girard, M., Renault-Miskovsky, J., 1969. Nouvelles techniques de préparation en Palynologie appliquées à 3 sédiments du Quaternaire final de l'abri Cornille (Istres, Bouches du Rhône). Bull. AFEQ 4, 275-284.

Goeury, C., 1988. Acquisition, gestion et représentation des données de l'analyse pollinique sur micro-ordinateur. Institut Français de Pondichery, Travaux de la Section Scientifique et Technique XXV, pp. 405-416 (http://www.imep-cnrs.com/ pages/gpalwin.htm).

Guilloré, P., 1980. Méthode de fabrication mécanique et en série des lames minces. Institut National d'Agronomie, Paris-Grignon (22 pp.).

Guillot, P.L., Feys, R., Lefavrais-Raymond, A., Platel, J.P., Lefavrais-Henry, M., Bassoulet, J.P., Contini, D., Gourdon-Platel, N., Quarantotti, J.C., Vanacker, J.C., Toilliez, L., Parfenoff, A., undated. 1:50 000 Geological map of France, sheet of Terrasson. BRGM: Orléans, 51 pp.

Haesaerts, P., Mestdagh, H., Bosquet, D., 1999. The sequence of Remicourt (Hesbaye, Belgium): new insights on the pedo- and chronostratigraphy of the Rocourt soil. Geol. Belg. 2 (3-4), 5-27.

Harris, C., Ellis, S., 1980. Micromorphology of soils in soliflucted materials, okstindan, Northern Norway. Geoderma 23, 11-29.

Havinga, A.J., 1984. A 20-years experimental investigation into the differential corrosion susceptibility of pollen and spores in various soil types. Pollen Spores XXVI (3-4), 541-558.

Helmens, K.F., 2014. The Last Interglacial-Glacial cycle (MIS 5e2) re-examined based on long proxy records from central and Northern Europe. Quat. Sci. Rev. 86, 115-143.

Jalut, G., Andrieu, V., Delibrias, G., Fontugne, M., Pages, P., 1988. Palaeoenvironment fo the Valley of Ossau (Western French Pyrenees) during the last 27000 years. Pollen Spores 25, 357-394.

Jomelli, V., Bertran, P., 2001. Humid snow avalanche deposits in the French Alps. Geogr. Ann. 83A (1-2), 15-28.

Kelts, K.R., Hsü, K.J., 1978. Freshwater carbonate sedimentation. In: Lerman, A. (Ed.), Lakes: Chemistry, Geology, Physics. Springer Verlag, New York, pp. 295-333.

Koch, K., 1989-1992. Die Käfer Mitteleuropas, Ökologie 1, 2 \& 3. Goecke \& Evers, Krefeld (440, 382 and 389 pp.).

Lambinon, J., Delvosalle, L., Duvigneaud, J., et al., 2004. Nouvelle Flore de la Belgique, du GrandDuché de Luxembourg, du Nord de la France et des Régions voisines. fifth ed. Éditions du Patrimoine du Jardin Botanique National de Belgique, Meise.

Lecoq, M., 1990. Une nouvelle localité française de Trechus (Epaphius) rivularis Gyll. (Col. Carabidae Trechinae). L'Entomologiste 46 (6), 278.

Leguédois, S., Party, J.P., Dupouey, J.L., Gauquelin, T., Gégout, J.C., Lecareux, C., Badeau, V., Probst, A., 2015. La carte de végétation du CNRS à l'ère du numérique. Cybergeo Eur. J. Geogr. http://dx.doi.org/10.4000/cybergeo.24688 (document 559 (http://cybergeo. revues.org/24688)).

Lindroth, C.H., 1985-1986. The Carabidae (Coleoptera) of Fennoscandia and Denmark. Fauna Entomologica Scandinavica 15. Brill, Scandinavian Science Press, LeidenCopenhagen (497 pp.).

Locht, J.L., Antoine, P., Bahain, J.J., Dwrila, G., Raymond, P., Limondin-Lozouet, N., Gauthier, A., Debenham, N., Frechen, M., Rousseau, D.D., Hatté, C., Haesaerts, P., Metsdagh, H., 2003. Le gisement paléolithique moyen et les sequences pléistocènes de VilliersAdam (Val-d'Oise). Chronostratigraphie, environnement et implantations humaines. Gallia Préhistoire 45, 1-111. 
Locht, J.L., Hérisson, D., Goval, E., Cliquet, D., Huet, B., Coutard, S., Antoine, P., Feray, P., 2015. Timescales, space and culture during the Middle Palaeolithic in northwestern France. Quat. Int. (online 28 September 2015 (http://dx.doi.org/10.1016/j.quaint. 2015.07.053)).

Loke, M.H., 2014. Electrical Imaging Surveys for Environmental and Engineering Studies. Tutorial:

2-D and 3-D Electrical Imaging Surveys. http://www.geoelectrical.com.

Loke, M.H., Acworth, I., Dahlin, T., 2003. A comparison of smooth and blocky inversion methods in 2D electrical imaging surveys. Explor. Geophys. 34, 182-187.

Lucas-Tooth, H.J., Price, B.J., 1961. A mathematical method for the investigation of interelement effects in X-ray fluorescence analysis. Metallurgia 64, 149-152.

Martin-Fernandez, J.A., Barcelo-Vidal, C., Pawlowsky-Glahn, V., 2003. Dealing with zeros and missing values in compositional data sets using nonparametric imputation.

Math. Geol. 35 (3), 253-278.

Miall, A.D., 1996. The Geology of Fluvial Deposits. Springer, Berlin.

Miedema, R., Koulechova, I.N., Gerasimova, M.I., 1999. Soil formation in Greyzems in Moscow district: micromorphology, chemistry, clay mineralogy and particle size distribution. Catena 34, 315-347.

Murray, A.S., Wintle, A.G., 2000. Luminescence dating of quartz using an improved singlealiquot regenerative-dose aliquot. Radiat. Meas. 32, 57-73.

Paulian, R., Baraud, J., 1982. Lucanoidea et Scarabaeoidea. Faune des Coléoptères de France 2, Encyclopédie Entomologique XLIII. Lechevalier, Paris (478 pp.).

Ponel, P., 1995. Rissian, Eemian and Würmian Coleoptera assemblages from La Grande Pile (Vosges, France). Palaeogeogr. Palaeoclimatol. Palaeoecol. 114, 1-41.

Quinif, Y., 2010. Fantômes de roche et fantômisation - Essai sur un nouveau paradigme en karstogenèse. Karstologia Mém. 18 (196 pp.).

Rameau, J.-C., Mansion, D., Dume, G., 1993. Flore forestière française: guide écologique illustré. T. 2: Montagnes. Institut pour le développement forestier, Paris (2421 pp.).

Rasmussen, S.O., Bigler, M., Blockley, S.P., Blunier, T., Buchardt, S.L., Clausen, H.B., Cvijanovic, I., Dahl-Jensen, D., Johnsen, S.J., Fischer, H., Gkinis, V., Guillevic, M., Hoek, W.Z., Lowe, J.J., Pedro, J.B., Popp, T., Seierstad, I.K., Steffensen, J.P., Svensson, A.M., Vallelonga, P., Vinther, B.M., Walker, M.J.C., Wheatley, J.J., Winstrup, M., 2014. A stratigraphic framework for abrupt climatic changes during the Last Glacial period based on three synchronized Greenland ice-core records: refining and extending the INTIMATE event stratigraphy. Quat. Sci. Rev. 106, 14-28.

Reille, M., 1990. Leçons de Palynologie et d'analyse pollinique. CNRS, Paris (206 pp.).

Salminen, R., 2005. Geochemical atlas of Europe. Foregs, IUGS/IAGC Global Geochemical Baselines. weppi.gtk.fi/publ/foregsatlas/index.php.

Sánchez-Goñi, M.F., Landais, A., Fletcher, W.J., Naughton, F., Desprat, S., Duprat, J., 2008. Contrasting impacts of Dansgaard-Oeschger events over a western European latitudinal transect modulated by orbital parameters. Quat. Sci. Rev. 51, 1136-1151.

Sánchez-Goñi, M.F., Harrison, S.P., 2010. Millennial-scale climate variability and vegetation changes during the Last Glacial: concepts and terminology. Quat. Sci. Rev. 29, 2823-2827.

Sánchez-Goñi, M.F., Bakker, P., Desprat, S., Carlson, A.E., Van Meerbeeck, C.J., Peyron, O., Naughton, F., Fletcher, W.J., Eynaud, F., Rossignol, L., Renssen, H., 2012. European climate optimum and enhanced Greenland melt during the Last Interglacial. Geology 40 (7), 627-630.

Sánchez-Goñi, M.F., Bard, E., Landais, A., Rossignol, L., d'Errico, F., 2013. Air-sea temperature decoupling in Western Europe during the last interglacial-glacial transition. Nat. Geosci. http://dx.doi.org/10.1038/NGEO1924. 
Thio-Henestrosa, S., Comas, M., 2011. CoDaPack v.2 user's guide. http://ima.udg.edu/ codapack/assets/codapack-manual.pdf.

Tronquet, M., 2014. Catalogue des Coléoptères de France. Association Roussillonnaise d'Entomologie, Perpignan (1052 pp.).

Van Steijn, H., 1996. Debris flow magnitude-frequency relationships for mountainous regions of Central and Northwest Europe. Geomorphology 15, 259-273.

Van Vliet-Lanoë, B., 1985. Frost effects in soils. In: Boardman, J. (Ed.), Soils and Quaternary Landscape Evolution. Wiley, Chicherster, pp. 117-158.

Van Vliet-Lanoë, B., 2010. Frost action. In: Stoops, G., Marcelino, V., Mees, F. (Eds.), Interpretation of Micromorphological Features of Soils and Regoliths. Elsevier, pp. 81-108.

Woillard, G., Mook, W.G., 1982. Carbon-14 dates at Grande Pile: correlation of land and sea chronologies. Science 215, 159-161.

Zanetti, A., 1987. Coleoptera Omaliinae. Fauna d'Italia 25. Calderini, Bologna (472 pp.). 

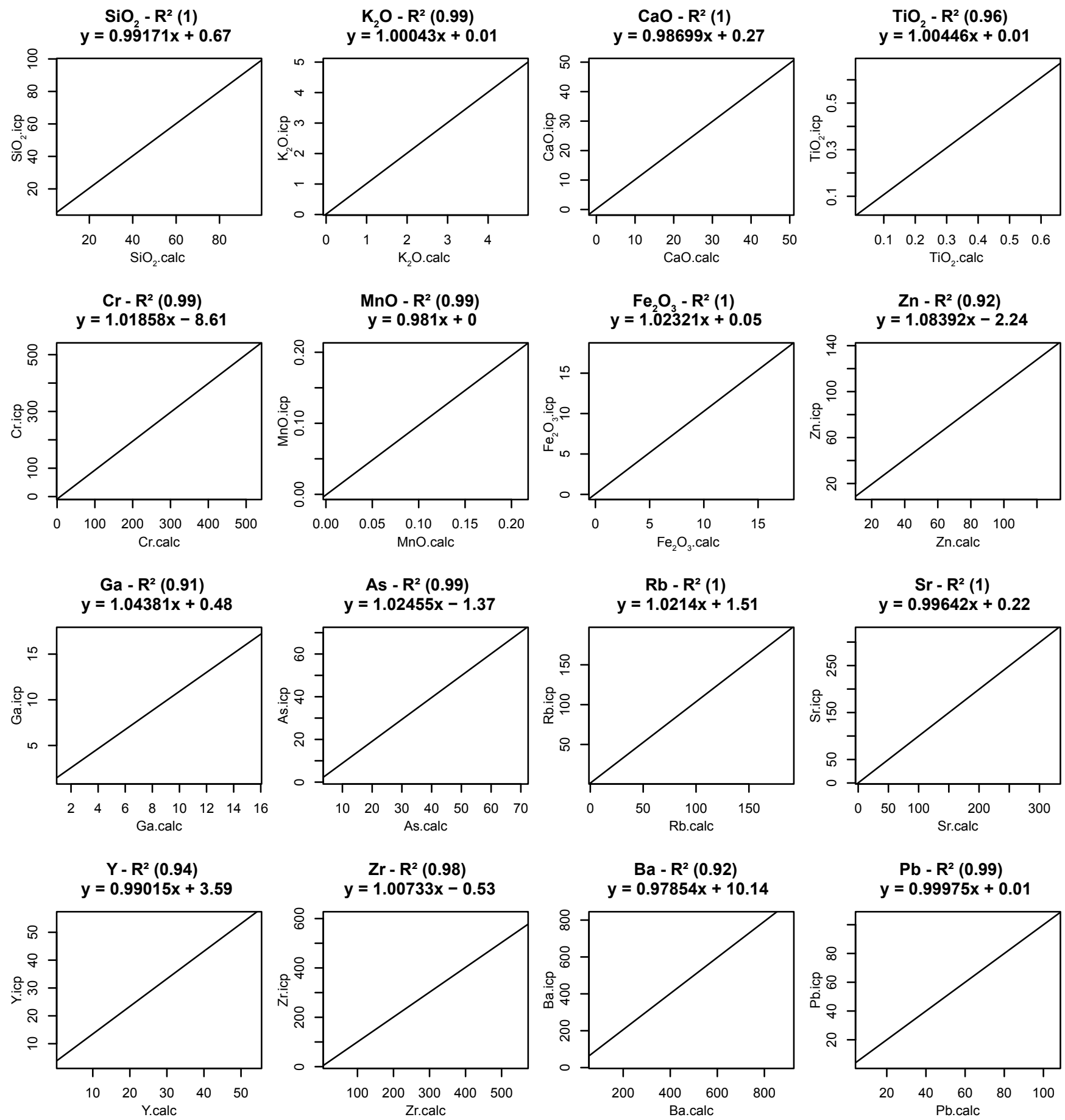

Figure SI_1: Correlation between measured (ICP/MS-ICP/AES, icp) and calculated (ED-XRF, calc) contents of major elements, presented as percent by weight of oxides, and minor or trace elements as part per million (ppm) by weight. The number of samples used for each element in the calibration process ranges from 13 to 16 depending on the detection limits of either the ED-XRF or the ICP-AES devices. 


\begin{tabular}{|c|c|c|c|c|c|c|c|c|c|c|c|c|c|c|c|c|}
\hline \multicolumn{17}{|c|}{ - SS2 (ind. excluded from the sum) } \\
\hline Sample $n^{\circ}$ & 62 & 60 & 58 & 54 & 49 & 45 & 40 & 35 & 30 & 25 & 24 & 19 & 15 & 12 & 9 & 7 \\
\hline Pinus & 1,1 & 1,1 & 2 & 3,8 & 5 & 3,9 & 7,3 & 5,9 & 1,9 & 4,4 & 12 & 6,3 & 11 & 5,9 & 4,6 & $\overline{5,3}$ \\
\hline Juniperus & 0,4 & 0,6 & 0 & 0 & 0 & 0,7 & 0 & 0 & 0,6 & 0 & 0 & 0 & 0 & 0 & 0 & 0,7 \\
\hline Betula & 1,5 & 0 & 0 & 0 & 1 & 0 & 2,1 & 1 & 1,3 & 0 & 0 & 1,6 & 1,3 & 0 & 0 & 0 \\
\hline Corylus $t$. & 0 & 0 & 0 & 0 & 0 & 0 & 0 & 0 & 0 & 1,1 & 0 & 1,6 & 0 & 0 & 0 & 0,7 \\
\hline Picea & 0 & 0 & 0 & 0 & 0 & 0 & 0 & 1 & 0 & 0 & 0 & 0 & 0 & 0 & 0 & 0 \\
\hline Salix & 0 & 2,3 & 3 & 4,8 & 13 & 18 & 10 & 2 & 20 & 0 & 0 & 0 & 0 & 0 & 0,8 & 0 \\
\hline Alnus & 0,4 & 0,6 & 0 & 0 & 0 & 0 & 0 & 0 & 0 & 0 & 0 & 0 & 0 & 0 & 0 & 0 \\
\hline Ericaceae & 0,4 & 0 & 0,5 & 0 & 1 & 0,7 & 3,1 & 1 & 0,6 & 1,1 & 0,9 & 0 & 1,3 & 1,7 & 0,8 & 2 \\
\hline Ephedra & 0 & 0 & 0 & 0 & 0 & 0 & 1 & 1 & 0 & 0 & 0 & 0 & 0 & 0 & 0 & 0 \\
\hline A.P. & 3,8 & 4,5 & 5,6 & 8,6 & 20 & 23 & 24 & 12 & 25 & 6,6 & 13 & 9,4 & 13 & 7,6 & 6,1 & 8,7 \\
\hline Helianthemum & 1,9 & 1,1 & 1 & 0 & 1 & 0 & 0 & 1 & 0 & 0 & 0 & 0 & 0 & 0,8 & 0 & 0,7 \\
\hline Arter & 16 & 11 & 9,1 & 1 & 4 & 2 & 1 & 1 & 1,9 & 0 & 0 & 0 & 1,3 & 0 & 1,5 & 2 \\
\hline Rubia & 0,4 & 0 & 0,5 & 1 & 2 & 2 & 2,1 & 2,9 & 1,3 & 2,2 & 2,6 & 0 & 3,9 & 0,8 & 2,3 & 1,3 \\
\hline laceae & 1,5 & 0,6 & 0,5 & 0 & 0 & 0 & 1 & 1 & 0,6 & 2,2 & 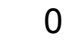 & 0 & 0 & 1,7 & 3,1 & 1,3 \\
\hline Planta & 0,4 & 2,3 & 1 & 0 & 0 & 0,7 & 2,1 & 1 & 0 & 0 & 0,9 & 1,6 & 1,3 & 0,8 & 0 & 0,7 \\
\hline diaceae & 1,9 & 0,6 & 0,5 & 0 & 2 & 1,3 & 2,1 & 2 & 0,6 & 0 & 0 & 0 & 0 & 0,8 & 0 & 0,7 \\
\hline Centaurea collina $t$. & 0,4 & 0 & 0 & 0 & 0 & 0 & 0 & 1 & 0 & 0 & 0 & 0 & 0 & 0,8 & 0 & 0 \\
\hline Campanulaceae & 0 & 0 & 0 & 0 & 0 & 0 & 0 & 0 & 0 & 0 & 0 & 0 & 1,3 & 0 & 0 & 0 \\
\hline Urticaceae & 0 & 0 & 0 & 0 & 0 & 0 & 0 & 0 & 0,6 & 0 & 0 & 0 & 0 & 0 & 0 & 0 \\
\hline Bras & 1,1 & 0,6 & 0,5 & 1 & 1 & 2 & 2,1 & 1 & 0 & 2,2 & 7 & 1,6 & 1,3 & 0 & 3,1 & 0 \\
\hline Aste & 5,3 & 1,1 & 1,5 & 1,9 & 4 & 3,3 & 4,2 & 4,9 & 2,6 & 4,4 & 0,9 & 1,6 & 3,9 & 0,8 & 0,8 & 2 \\
\hline Cich & 13 & 0,6 & 0,5 & 2,9 & 5 & 2,6 & 6,3 & 11 & 2,6 & 1,1 & 6,1 & 7,8 & 13 & 7,6 & 6,9 & 2 \\
\hline Caro & 0,4 & 0 & 0 & 0 & 0 & 0 & 0 & 1 & 0 & 1,1 & 0 & 0 & 0 & 0 & 0 & 0 \\
\hline Thali & 1,9 & 0,6 & 0 & 0 & 0 & 0 & 0 & 0 & 0 & 0 & 0 & 0 & 0 & 0 & 0 & 0 \\
\hline Arm & 0,4 & 0 & 0 & 0 & 0 & 0 & 0 & 0 & 0 & 0 & 0 & 0 & 0 & 0 & 0 & 0 \\
\hline Poa & 37 & 22 & 21 & 17 & 16 & 15 & 32 & 27 & 20 & 22 & 23 & 19 & 37 & 19 & 27 & 31 \\
\hline Faba & 0 & 0 & 0 & 0 & 0 & 0 & 1 & 1 & 0 & 0 & 0,9 & 0 & 0 & 1,7 & 0,8 & 0,7 \\
\hline Apiaceae & 2,7 & 0 & 1 & 1 & 1 & 1,3 & 2,1 & 2 & 0 & 0 & 0,9 & 6,3 & 0 & 0,8 & 4,6 & 2 \\
\hline Rumex & 0 & 0 & 1 & 0 & 0 & 0 & 0 & 0 & 0 & 1,1 & 0 & 1,6 & 1,3 & 0,8 & 0,8 & 0 \\
\hline Lamiacea & 0,8 & 0 & 0 & 0 & 0 & 0 & 0 & 0 & 0 & 0 & 0 & 1,6 & 0 & 0 & 0 & 0 \\
\hline Gentia & 0 & 0 & 0 & 0 & 0 & 0 & 0 & 0 & 0 & 0 & 0 & 0 & 0 & 0 & 0,8 & 0 \\
\hline Eup & 0 & 0 & 0 & 0 & 0 & 0 & 0 & 0 & 0 & 0 & 0 & 0 & 0 & 0,8 & 0 & 0 \\
\hline Val & 0,4 & 0 & 0 & 0 & 0 & 0 & 0 & 0 & 0 & 0 & 0,9 & 0 & 0 & 0 & 0 & 0 \\
\hline Scr & 0,4 & 0 & 0,5 & 0 & 0 & 0 & 1 & 0 & 0 & 0 & 0 & 0 & 0 & 0 & 0 & 0 \\
\hline Papa & 0 & 0 & 0,5 & 0 & 0 & 0 & 0 & 0 & 0 & 0 & 0 & 0 & 0 & 0 & 0 & 0 \\
\hline raceae & 0 & 0 & 0 & 0 & 0 & 0 & 1 & 0 & 0 & 0 & 0 & 0 & 0 & 0 & 0 & 0 \\
\hline Filipendula & 0 & 1,1 & 1 & 0 & 0 & 0 & 0 & 0 & 0 & 0 & 0 & 0 & 0 & 0,8 & 0 & 0 \\
\hline Rosaceae & 0 & 0 & 0,5 & 0 & 0 & 1,3 & 1 & 0 & 0 & 1,1 & & 0 & 0 & 0 & 0 & 0 \\
\hline Ran & 0,4 & 0 & 0,5 & 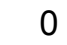 & 0 & 0 & 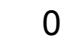 & 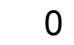 & 0 & 0 & 0,9 & 0 & 0 & $u$ & 0 & 0,7 \\
\hline Cyper & 9,9 & 51 & 54 & 65 & 43 & 44 & 17 & 30 & 45 & 55 & 43 & 50 & 22 & 53 & 39 & 46 \\
\hline Hydrocharis t.? & 0 & 3,4 & 0 & 0 & 0 & 0 & 0 & 0 & 0 & 0 & 0 & 0 & 0 & 0 & 0 & 0 \\
\hline Potam & 0 & 0,6 & 0 & 0 & 1 & 0 & 0 & 0 & 0 & 0 & 0 & 0 & 0 & 0 & 0,8 & 0 \\
\hline Monoletes & 0 & 0 & 0 & 0 & 0 & 0,7 & 0 & 0 & 0 & 0 & 0 & 0 & 0 & 0 & 0,8 & 0 \\
\hline Triletes & 0 & 0 & 0 & 0 & 1 & 0 & 0 & 0 & 0 & 0 & 0 & 0 & 0 & 0 & 1,5 & 0 \\
\hline$S p$ & 0,8 & 0 & 0 & 0 & 0 & 0,7 & 0 & 0 & 0 & 1,1 & 0 & 0 & 0 & 0,8 & 0,8 & 0,7 \\
\hline Ind. / total & 19 & 13 & 17 & 20 & 9,8 & 12 & 28 & 22 & 23 & 17 & 15 & 7,3 & 19 & 13 & 15 & 14 \\
\hline
\end{tabular}

Table SI_1: Pollen frequencies in the peat sequence of core SS2. 


\begin{tabular}{|c|c|c|c|c|c|c|c|c|c|}
\hline \multicolumn{10}{|c|}{ Montignac - Lascaux 4 - SS5 (ind. excluded from the sum) } \\
\hline sample $n^{\circ}$ & 40 & 37 & 30 & 26 & 19 & 16 & 12 & 7 & 到 \\
\hline Pinus & 2,66 & 2,15 & 3,92 & 2,61 & 2,95 & 0,48 & 4,54 & 3,51 & 9,06 \\
\hline Betula & 0 & 0,43 & 0 & 0 & 0 & 0,48 & 0 & 0,39 & 0,27 \\
\hline Juniperus & 0,66 & 0 & 0,39 & 0 & 0 & 0 & 0 & 0 & 0 \\
\hline Ephedra & 0,33 & 0,43 & 0 & 0,65 & 0 & 0 & 0,45 & 0 & 0,27 \\
\hline Ericaceae & 0,66 & 0 & 0,78 & 0 & 0,42 & 0 & 0 & 0,78 & 1,64 \\
\hline Corylus $t$. & 0 & 0,43 & 0 & 0 & 0,42 & 0,48 & 0 & 0 & 0,27 \\
\hline Salix & 7,66 & 14,22 & 6,27 & 5,88 & 11,39 & 13,46 & 6,36 & 14,45 & 0,82 \\
\hline Alnus & 0 & 0 & 0 & 0 & 0 & 0 & 0 & 0 & 0,27 \\
\hline Carpinus & 0,33 & 0 & 0 & 0 & 0 & 0 & 0 & 0,39 & 0 \\
\hline A.P. & 12,3 & 17,66 & 11,36 & 9,14 & 15,18 & 14,9 & 11,35 & 19,52 & 12,6 \\
\hline Artemisia & 1 & 0,43 & 0,39 & 7,84 & 1,26 & 1,44 & 0,9 & 0,39 & 0,54 \\
\hline Helianthemum & 0 & 0 & 0,39 & 1,96 & 0,42 & 0,48 & 0,45 & 0 & 0 \\
\hline Rubiaceae & 0,66 & 0 & 0,78 & 3,26 & 1,26 & 2,4 & 0 & 1,17 & 1,09 \\
\hline Plantagc & 0,33 & 0,86 & 0,39 & 0,65 & 0,84 & 0,96 & 0,45 & 0,78 & 0,82 \\
\hline diaceae & 0,66 & 0,43 & 0,39 & 1,96 & 1,68 & 1,92 & 1,36 & 1,17 & 1,37 \\
\hline Thalictrum & 0,33 & 0 & 0 & 0,65 & 0 & 0,48 & 0,45 & 0 & 0,27 \\
\hline Caryophyllaceae & 0,33 & 0,43 & 0,39 & 0,65 & 1,26 & 0,96 & 0,9 & 0,78 & 1,09 \\
\hline Brassicaceae & 0,66 & 1,72 & 1,96 & 2,61 & 1,68 & 5,76 & 0,45 & 3,12 & 2,19 \\
\hline nulaceae & 0 & 0,43 & 0,39 & 0 & 0 & 0 & 0 & 0 & 0 \\
\hline Urtica & 0 & 0 & 0 & 0 & 0 & 0 & 0,45 & 0 & 0 \\
\hline Centaurea collina $t$. & 0 & 0 & 0,39 & 0 & 0,42 & 0 & 0,45 & 0 & 0,54 \\
\hline Centaurea sp. & 0 & 0 & 0 & 0 & 0 & 0 & 0 & 0,39 & 0 \\
\hline Carduc & 0,33 & 0 & 0 & 0 & 0 & 0 & 0,45 & 0 & 0 \\
\hline Aster & 0,66 & 1,29 & 1,56 & 6,53 & 1,26 & 6,73 & 0,9 & 1,56 & 4,12 \\
\hline Cich & 7,66 & 1,29 & 3,13 & 16,33 & 6,75 & 23,55 & 3,18 & 3,12 & 13,18 \\
\hline Poa & 18 & 16,81 & 23,92 & 26,79 & 23,62 & 27,4 & 19,54 & 15,62 & 31,31 \\
\hline Apiac & 0,33 & 0,43 & 1,56 & 1,96 & 1,26 & 0,96 & 0 & 1,17 & 0,82 \\
\hline Fabac & 0,33 & 0,43 & 0,39 & 0 & 0,42 & 0 & 0,9 & 0,78 & 0 \\
\hline Rumex & 0,33 & 0 & 0,78 & 0 & 0,42 & 0 & 0 & 0 & 0 \\
\hline Lamiaceae & 0 & 0 & 0 & 0 & 0 & 0 & 0,45 & 0 & 0,27 \\
\hline Scrofulariaceae & 0 & 0 & 0 & 0 & 0 & 0 & 0 & 0,39 & 0,27 \\
\hline Rosaceae sp. & 0,33 & 0,86 & 1,17 & 1,3 & 0,42 & 0,48 & 0,9 & 0,39 & 0,27 \\
\hline Filipendula & 0 & 0 & 0 & 0 & 0 & 0,48 & 0 & 0 & 0,27 \\
\hline Sanguisorba officinalis & 0 & 0 & 0 & 0 & 0,42 & 0 & 0 & 0 & 0,27 \\
\hline Liliaceae & 0 & 0,43 & 0 & 0 & 0,42 & 0 & 0,45 & 0 & 0 \\
\hline Cyperaceae & 16,66 & 54,74 & 50,58 & 18,3 & 40,08 & 10,57 & 55 & 48,82 & 26,37 \\
\hline Alismataceae & 0 & 0,43 & 0 & 0 & 0 & 0 & 0 & 0 & 0 \\
\hline Potamogeton & 0 & 0,86 & 0 & 0 & 0 & 0 & 0 & 0 & 0,82 \\
\hline Monoletes & 0 & 0 & 0 & 0 & 0,42 & 0 & 0,45 & 0 & 0 \\
\hline Triletes & 0 & 0 & 0 & 0 & 0 & 0,48 & 0 & 0 & 0 \\
\hline Sphagnu & 0 & 0,43 & 0 & 0 & 0,42 & 0 & 0,45 & 0,78 & 1,37 \\
\hline Indeterminated & 22 & 16,8 & 21 & 37,8 & 19,6 & 28,5 & 17,9 & 15,2 & 13,33 \\
\hline
\end{tabular}

Table SI_2: Pollen frequencies in the peat sequence of core SS5. 


\begin{tabular}{|c|c|c|c|c|c|c|c|c|c|c|c|c|c|c|c|c|c|c|c|c|c|}
\hline 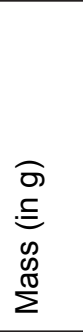 & 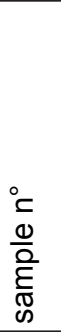 & \begin{tabular}{l}
0 \\
$d$ \\
\multirow{2}{c}{} \\
c \\
$\frac{0}{0}$ \\
$\frac{1}{0}$ \\
$\frac{c}{0}$ \\
0
\end{tabular} & 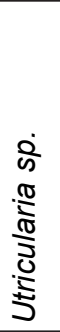 & $\begin{array}{l}0 \\
\mathbb{0} \\
0 \\
0 \\
\frac{\pi}{0} \\
0 \\
\frac{0}{2} \\
0\end{array}$ & 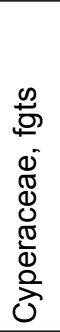 & 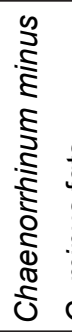 & 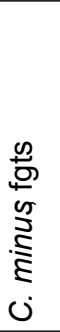 & $\begin{array}{l}\frac{\pi}{0} \\
\stackrel{0}{J} \\
\frac{\pi}{\pi} \\
0 \\
0 \\
0 \\
0 \\
0\end{array}$ & 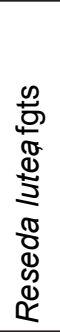 & 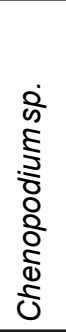 & $\begin{array}{l}\dot{2} \\
\text { के } \\
\frac{1}{0} \\
\frac{1}{\pi} \\
\frac{0}{0} \\
0\end{array}$ & $\begin{array}{l} \\
0 \\
\mathbb{8} \\
0 \\
0 \\
\frac{\pi}{0} \\
\frac{1}{0} \\
\frac{1}{4}\end{array}$ & 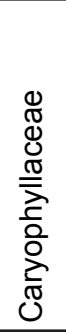 & $\begin{array}{l}0 \\
0 \\
\mathbb{8} \\
0 \\
0 \\
0 \\
0 \\
0\end{array}$ & 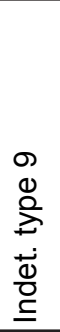 & 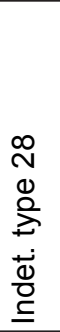 & $\begin{array}{l}\text { 无 } \\
\text { 음 }\end{array}$ & 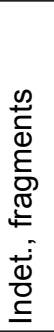 & 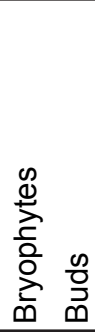 & 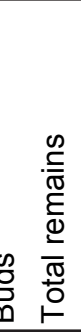 & 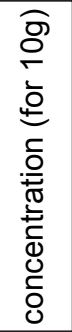 \\
\hline 29 & 1 & & 1 & 1 & & & & & & & & & & & & & & & & 2 & 0,7 \\
\hline 30 & 5 & & & 2 & 4 & & & & & & & & & & & & & & & 6 & 2 \\
\hline 46,5 & 6 & 1 & 1 & 1 & 3 & & & & & & & & & & & & & 1 & & 7 & 1,5 \\
\hline 34 & 9 & & & & & & & & & & & & & & 2 & & & & & 2 & 0,6 \\
\hline 39,5 & 10 & & 8 & & & & & & & & & & & & & & & & $* * * *$ & 8 & 2 \\
\hline 41,5 & 11 & & 6 & & & & & 1 & & & & & & & & & 3 & & & 10 & 2,4 \\
\hline 43,5 & 12 & & 4 & 2 & 3 & & & 1 & 2 & & 1 & & & & & & 2 & & & 15 & 3,5 \\
\hline 41 & 13 & & 2 & 16 & 18 & & 2 & & & & & & & & & & & & & 38 & 9,3 \\
\hline 35 & 14 & & & 2 & 1 & & & & & & & & & 1 & & & & & & 4 & 1,1 \\
\hline 42 & 16 & & 5 & & & & & & & & & & & & & & & & & 5 & 1,2 \\
\hline 30,5 & 17 & & 3 & & & & & & & & & & & & & & & & $* * *$ & 3 & 1 \\
\hline 42,5 & 18 & & & & & & 1 & & & & & 1 & & & & & & & & & 0,5 \\
\hline 42 & 19 & & 4 & & & & & & & & & & & & & & & & & 4 & 1 \\
\hline 42 & 20 & & & & & & & & & & & & 1 & & & & & & & 1 & 0,2 \\
\hline 25,5 & 21 & & 1 & 1 & 3 & & 3 & & & & & & & & & & & & & 8 & 3,1 \\
\hline 22 & 22 & & & & & & 1 & & & & & & & & & & & & & 1 & 0,5 \\
\hline 27 & 23 & & 1 & 1 & & 2 & 1 & & & & & & & & & & & & & 5 & 1,9 \\
\hline 36 & 24 & & & & & & & & & & 1 & & & & & & & & 1 & 2 & 0,6 \\
\hline 42,5 & 25 & & 2 & & 2 & & & & & & 1 & & & & & & & & & 5 & 1,2 \\
\hline 39 & 26 & & 4 & & 2 & 2 & & & & & & & & & & & & & & 8 & 2,1 \\
\hline 30 & 27 & & & & 4 & & & & 1 & & & & & & & & & & & 5 & 1,7 \\
\hline 35 & 28 & & & 1 & 5 & & & & & & & & & & & 4 & & & & 10 & 2,9 \\
\hline 31 & 29 & & 3 & 1 & 7 & & & & & & & & & & & 1 & & & & 12 & 3,9 \\
\hline 39,5 & 30 & & 3 & & & & & & & & & & & & & & & 1 & & 4 & 1 \\
\hline 39 & 32 & & & & 2 & & & & & & & & 1 & & & & & & & 3 & 0,8 \\
\hline 41 & 33 & & & & & & & & & & & & & & 1 & & & & & 1 & 0,2 \\
\hline 48 & 35 & & & & & & & & & & & & & & & & & & $\star \star \star *$ & $\star * *$ & $* \star * * *$ \\
\hline 31 & 36 & & & & & & & & & & & & & & & & & & $* * *$ & $* * *$ & $\star * * *$ \\
\hline 35,2 & 37 & & & 1 & & & & & & & & & & & & & & & & 1 & 0,3 \\
\hline 30 & 38 & & 1 & & & & & & & & & & & & & & & & & 1 & 0,3 \\
\hline 48,5 & 39 & & & & 2 & & & & & & & & & & & & & & & 2 & 0,4 \\
\hline 28,5 & 40 & & & & & & & & & & & & & & & & 2 & & & 2 & 0,7 \\
\hline 31 & 41 & & & & 4 & & & & & & & & & & & & & & & 4 & 1,3 \\
\hline 40,5 & 42 & & 2 & 1 & 3 & & & & & & & & & & & 4 & & & & 10 & 2,5 \\
\hline 33,5 & 43 & & 2 & 1 & 2 & & & & & & & & & & & 1 & & & & 6 & 1,8 \\
\hline 27,5 & 44 & & 3 & & & & & & & & & & & & & 1 & & & & 4 & 1,5 \\
\hline 40 & 45 & & 1 & & 1 & & & & & & & & & & & 4 & & 1 & & 7 & 1,8 \\
\hline 31 & 46 & & 1 & & & & & & & & & & & & & & 1 & & & 2 & 0,6 \\
\hline 29,5 & 47 & & & 1 & & & & & & & & & & 1 & & 2 & & & & 4 & 0,1 \\
\hline 32 & 48 & & & & 3 & & & & & & & & & 1 & 1 & 6 & 1 & & & 113 & 4,1 \\
\hline 28,5 & 49 & & & 1 & 7 & & & & & & & 1 & & & & 4 & & & & 13 & 4,6 \\
\hline 29,5 & 50 & & & & & & & & & & & & & & 1 & 1 & & & & 2 & 0,7 \\
\hline 15 & 51 & & 1 & & & & & & & & & & & & & 3 & & & & 4 & 2,7 \\
\hline 37 & 52 & & & & 3 & & & & & & & & & & & & 3 & & & 6 & 1,6 \\
\hline 30 & 54 & & & 1 & 1 & & & & & & & & & & & & & & & 2 & 0,7 \\
\hline 14,5 & 55 & & & & & & & & & & & & & & & & & & $* \star *$ & $\star * *$ & $* * * *$ \\
\hline 19 & 56 & & & & 1 & & & & & & & & & & & & 1 & & ** 1 & 13 & 1,6 \\
\hline 37,5 & 59 & & & & & & & & & & & & & & & & & & 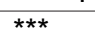 & $* * *$ & $* * * *$ \\
\hline 28 & 60 & & & & & & & & & & & & & & & & 2 & & 4 & 6 & 2,1 \\
\hline 44 & 62 & & & & & & & & & & & & & & & & 1 & & 2 & 3 & 0,7 \\
\hline 21 & 63 & & & & & & & & & 1 & & & & & & & & & & 1 & 0,5 \\
\hline
\end{tabular}

Table S_3: List of the macro-remains in core SS2. 


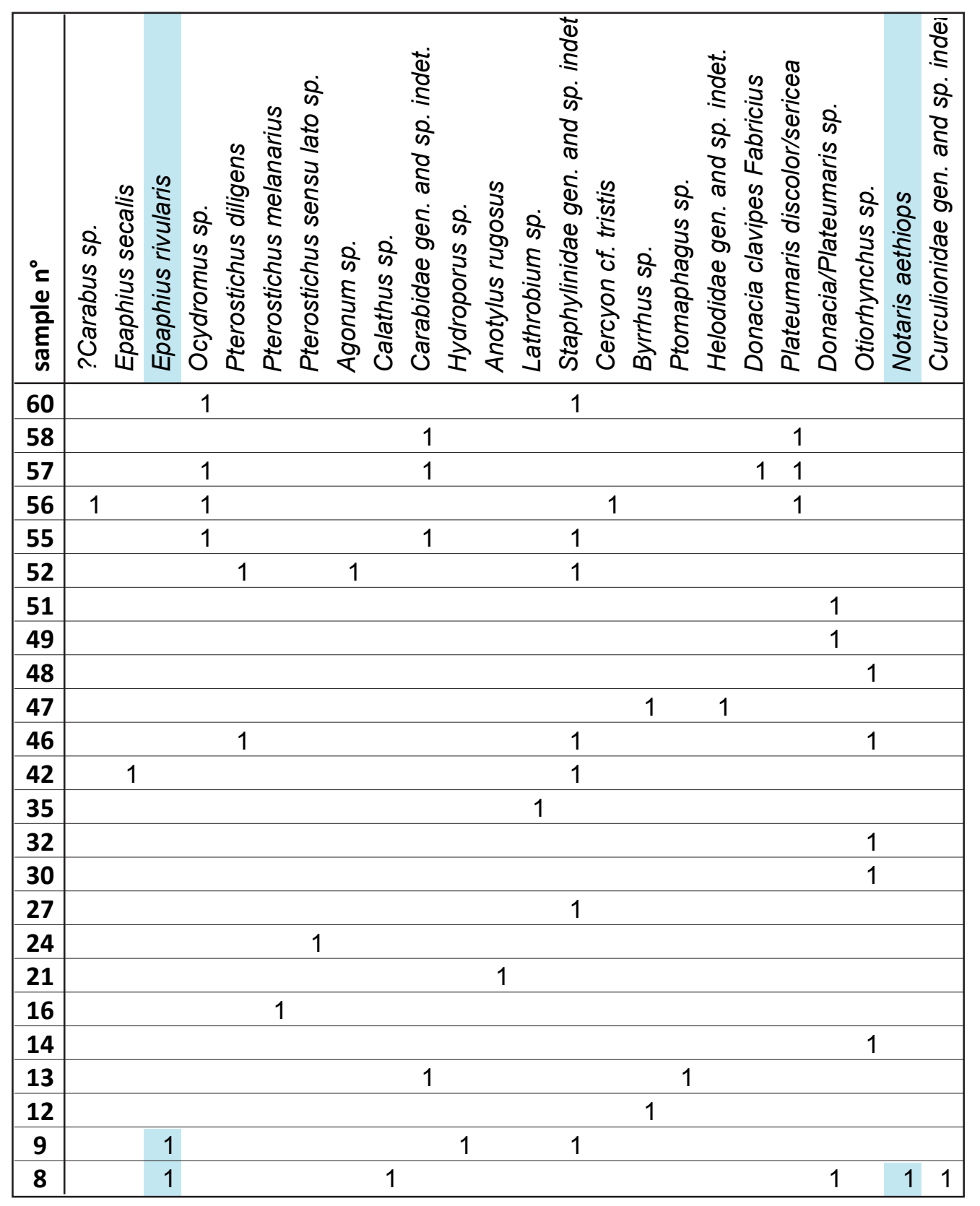

Table SI_4: List of the beetle taxa and minimal number of individuals in core SS2. The species indicator of a cold climate are highlighted in blue. 


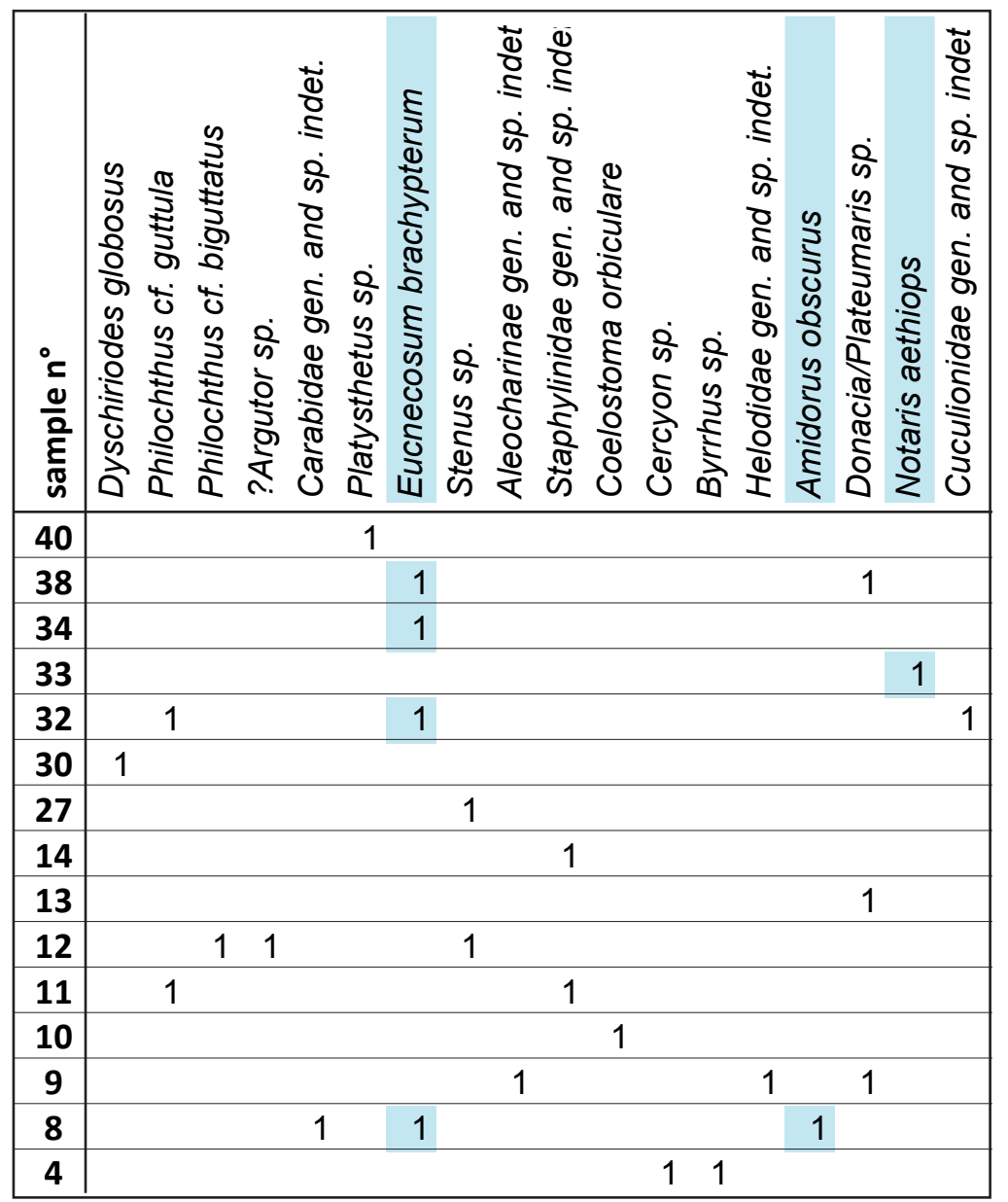

Table SI_5: List of the beetle taxa and minimal number of individuals in core SS5. The species indicator of a cold climate are highlighted in blue.

\begin{tabular}{|ll|}
\hline Montignac Trench 56/81.57 & \\
\hline Dyschiriodes globosus & 1 \\
Ocydromus sp. & 2 \\
Cymindis vaporariorum & 1 \\
Carabidae gen. and sp. indet. & 3 \\
Hydroporus sp. & 1 \\
Platysthetus cf. cornutus & 1 \\
Acidota crenata & 1 \\
Olophrum fuscum & 1 \\
Euaesthetus laeviusculus & 1 \\
Stenus sp. & 1 \\
Aleocharinae gen. and sp. indet. & 1 \\
Plateumaris discolor/sericea & 1 \\
Otiorhynchus rugifrons & 1 \\
\hline
\end{tabular}

Table SI_6: List of the beetle taxa and minimal number of individuals in sample "Montignac Trench 56/81.57". 